DEPARTMENT OF THE INTERIOR

UNITED STATES GEOLOGICAL SURVEY

CHARLES W. WALCOTT, DIRECTOR

Relation of the Law to Tnderground Waters

BY

\title{
DOUGLAS WILSON·JOHNSON
}

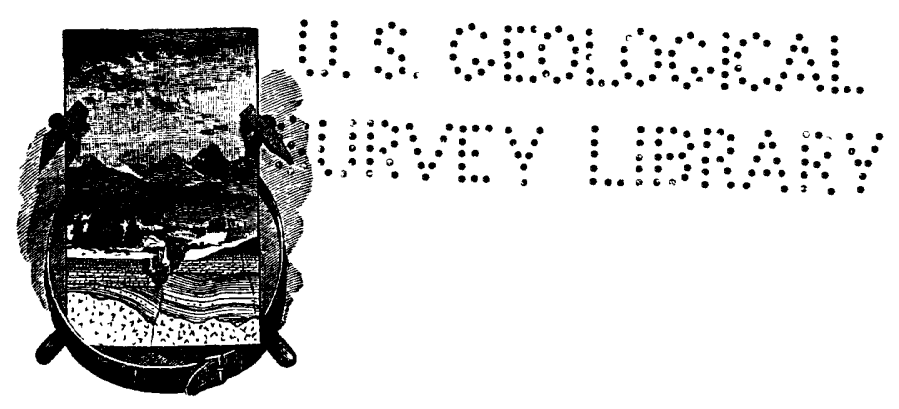

WASIIINGTON

GOVERNMENT IRINTING OFFICF

$19(1) 5$ 


\section{(OONENTS.}

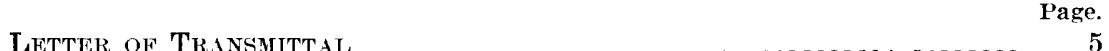

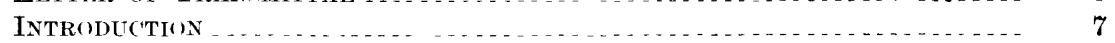

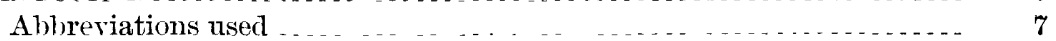

Chapter I. Common-law rules concerning undergronnd waters. ........ 9

Definition of nnderground waters .......................... 9

Classification of underground waters . . . . . .

Underground waters of the first class. . . . . . . . . . . . . . . . . . . 10

What constitutes underground waters of the first class . . . . . . . . 10

Laws relating to underground waters of the first class _ . . . . . . . 11

Underground waters of the second class . . . . . . . . . . . . . . . . . . 12

Laws relating to undergromnd waters of the second class ........ 12

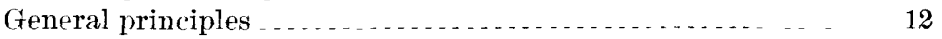

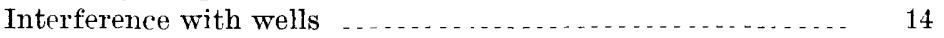

Interference with springs _. . . . . . . . . . . . . . . . . . . . 17

Interference with streams $\ldots \ldots \ldots \ldots \ldots$

Injury to land _...

Damming of underground waters ... . . . . . . . . . . . . . . 21

Disposal of intercepted underground waters ............. 21

Artificial production of percolation ..................... 22

Artificially increased percolation . . . . . . . . . . . . . . . . 23

Pollution of underground waters .................. 25

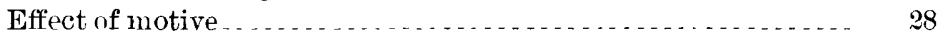

Effect of grant or acreement . . . . .

Effect of prescription . . . . . . . 31

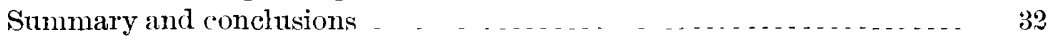

Gнартек II. Legislative aits affecting underground waters........... 39

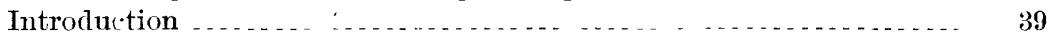

California .

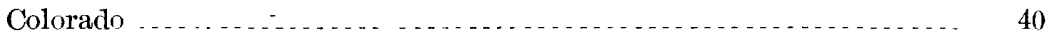

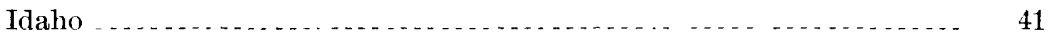

Michigan

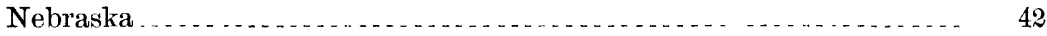

Nevada ...

New Jersey ...

New Mexico . . .

Oklalioma

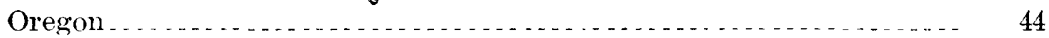

South Dakota

Utah

Washington . . . . .

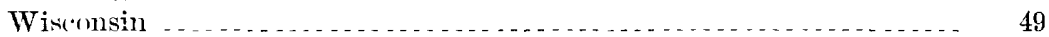

Wyoming ...

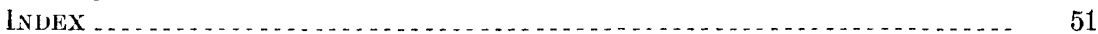




\title{
LETTER OF TRANSMITTAL.
}

\author{
Department of the INterior, \\ United States Grological Survey, \\ Hydrographic Branch, \\ Washington, I). ('., February $23,1905$.
}

SIR: I have the honor to transmit herewith a manuscript mutitled "Relation of the Law to Underground Waters," prepared by louglas Wilson Johnson at the request of Mr. M. I. Fuller, in charg: of the eastern section of the division of hydrology, and reconmend that it he published as a water-supply and irrigation paper.

This manuscript, which is the first comprehensive paper prepared in this country on the relation of the law to underground waters, was compiled to meet a considerable and ever-increasing demand for information as to the application of the law to this subject. It is especially pertinent at this time, when active efforts are being made in several States to enact laws governing the use of underground waters which shall take account of the recent advances in the science of hydrology and the present knowledge of the occurrence and movements of such waters.

Very respectfully,

Hon. Charles D. Walcott,

F. H. Newell, Chief Engineer.

Director Inited States Geological Survey. 


\title{
RELATION OF TIIE LAW TO INIDERGROUND WATERS.
}

\author{
By Doyglas Wilsin . Joinson.
}

\section{INTRODUTTION.}

The following pages represint an attempt to ontline the main features of the laws respecting underground waters, with the object of giving to the owner of such water's some idea of his rights and obligations concerning them. It is needles's to say that the report is in no sense a legal treatise, but rather an endea vor to collect and arrange such legal decisions as will serve to show the relation of the law to problems which are essentially geological in character. In summing up the general featuren of this law, I have recorded some observations which present themselves to the student of geology.

Throughout the preparation of the paper I have received much help from such authoritative works as John M. Gould's treatise on the "Law of Waters," Pomeroy's treatise on "Water Rights," the section of the American and English Encyclopedia of Law dealing with "Underground Waters," and the La wyer"s Reports Annotated. The original reports of all the cases here cited, as well as of many others, have been consulted in the endeavor to ascertain just what were the critical point upon which each was decided. I am indebted to Prof. John C. Gray, of the Harvarel Law School, and Mr. George Albert Walker, of the Boston bar, for valuable criticism.

\section{ABBREVIATIONS USED.}

Allen (Mass.) =-Nllen's Matssaldhusetts Reports.

Am. Dee.=American Derisions.

Ait. Law Reg. =- Amerilam Law Register.

Alp. cats = Apleal cases. English Law Reports.

B. \& S.=Best and Snitlis Fuglish Queen's linench Iieports

Barl. = Barlomr"s Supreme comert Reports, New York.

Rear.= Beavan's English Rolls court Reports.

Cal.=california lieprorts.

('ent. Rep).= c'entral Rejorter.

Ch. Div.=Chancery Division. English Law Reports.

Conn $=$ Connecticut Reports. 
Ct. of $\mathrm{Cl}=$ Court of Claims, United States.

Cush. (Mass.) = Cushing; Massachusetts Reports.

El. \& B1.=Ellis and Bladiburn's English Queen's Bench Reports.

Wl. \& El.= Ellis and Ellis's English Queen's Bench Reports.

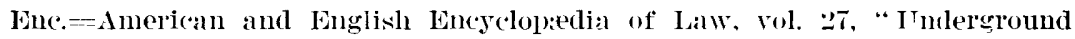
Waters," pl1. 423-44t.

Exch.=Exchequer Reports (Welsby, Hurlstone, and Gordon).

Gould =."A Treatise on the Law of Waters," third edition, by John M. Gould, Pli. D., Chicago, 1900.

II. \&. N.=Hurlstone and Norman's English Exrhequer Reports.

II. I. Cals. =-IIouse of Lords' Cases.

IIun=-=IIun's New York supreme Court Reports.

Ill. =-Illinois Reports.

Ind.=-Indiana Reports.

Iowa = Iowa Reports.

Jones' Eq.=-Jones's North Carolina Equity Reports.

Ky.=-Kentucky Reports.

L.=Laws (legislative acts of States and Territories).

I. R. $A=$ Law yer's Reports Amotated, Rochester, N. Y. (Lawyers" Cooperative Publishing Company).

I. R. C. P.=English Law Reports, Common I'leas.

L. R. ('h.=English Law Reports, Chancery, Appeal Cases.

I. R. H. I.=-English Jaw Reports, English and Irish Apleal cases.

I. R. P. C.=linglish Latw Reports, Privy Council, Alpeal ('ases.

L. T. N. S.=Law Times Reports, New Series.

M. \& W.=Meeson and Welshy's English Exchequer Reports.

Mass.= Massachusetts Reports.

Me.=-Maine Reports.

Mich.=Michigan Iieports.

N. Car. $==$ North Carolina Reports.

N. II.=-New IIamushire Reports.

N. Y.=New York Reports.

Ner. = Nerada Reports.

Ohio St.=Ohio state Reports.

Pac. Rep.=l'acific Reporter.

Penu. St. $=$ Penusylyania State Reports.

Pick. = I’ickering's Massar.husetts Iieports.

Pomeroy $=$ "A Treatise on the Law of Water Rights," by John Norton Pomeroy, LL. D., and IIenry C'ampbell Black, M. A., St. Paul, 1893.

Vt. $=$ Vermont Reports. 


\section{CH A P T E R I.}

\section{COMMON-TAW RULES CONCERNING ITNDFRGROTND WATERS.}

Of the water which falls upon the earth in the form of rain one portion suffers evaporation, a second portion escapes by direct runoff into surface streams, while a third portion sinks into the ground. The second portion, or that which escapes into surface streams. may find its way directly to the sea, with some loss by evaporation; or it may happen that an appreciable portion of this water will later sink below the surface and pursue for some time a subterranean course. The third portion, or that which at first passes directly into the ground, may later emerge to join surface streams, or may find it: way to the sea without ever reappearing at the surface. During the course of its journey underground, water may collect into more or less well-defined subterranean channels, or may pass through the general mass of porous earth by slow percolation.

\section{DEFINITION OF UNDERGROUND WATERS.}

It will be seen, then, that underground waters comprise all waters which are for the time being below the surface of the ground, whether they have reached their present position by penetrating the ground directly after the fall of rain, or by escape from such surface bodies of water as springs, swamps, lakes, rivers, etc.; whether they are confined to definite channels, or are dissipated throughout the mass of more or less porous ground; and whether they are ultimately to reach the sea without reappearing at the surface, or are soon to emerge as well-defined streams or numerous widely distributed springs.

\section{CLASSIFICATION OF UNDERGROUND WATERS.}

While recognizing the broad definition of underground waters given above, the law divides such waters into two distinct classes, and provides for each a different rule. This division is based on the method of transmission underground-whether in definite channels or by general percolation. It is evident that in many cases it would be impossible to know whether or not such underground transmission were in definite channels; and hence the law provides that where doubt exists the presumption shall be in favor of the ordinary percolation of water through the ground. Thus limited the law recog- 
nizes the two following classes of underground waters: (1) ITnderground colrents of water flowing in defined and known channels; (2) water passing throngh the gromd bencath the surface, either without definite channels or in courses which are unknown.

UNDERGROUND WATERS OF THE FIRST CLASS.

(Underground Waters Flowing in Defined and Known Channels.)

WIIT CONSTITUTES UNDERGROTTND WATERS OF TIIE FIRST CLASS.

The meaning of "defined and known" as here used is thus explained by Gould (558): "In this connection, "defined" means a contractert and bounded channel, though the course of the stream may be undefined by human knowledge, and 'known,' which is not here synonymous with "risible, refer's to knowlerlge by reasonable inference." When the water flows in an underground rhannel which could be ascertained only by excavations, such a channel is not considered as "known."

In order to be certain that a given subterranean flow comes within the scope of this class of underground waters, one must be able to show, without opening the ground by excavation, that the water flows in a definite channel. For example, it is sufficient for this purpose if one can show that a continnons stream channel exists, and that the water which disappears beneath sand and gravel in the bed of this channel at one point reappears farther downstream. This is often the case with streams in arid regions, whose raters appear at the surface only at occasional points along a channel which can be readily and continuously traced. In the case of Case $r$. Hoffman (L. R. A. 20, p. 40) it was held that "The flowing of water upon and beneath the surface of lands between a natural lake * * * and a creek into which they discharge constitutes a watercourse where the flow is all in the same direction and a part of the way along a distinct and plainly marked channel, although for some of the distance it spreads over wide reaches of marsh and swamp lands, and percolates the soil in many and most places between the lake and the creek."

If a stream flows into a sinkhole in a definite direction, pursues for a short space a subterranean course, and then emerges on the surface again, it is considered to have a definite and known channel. Even where a large stream pursues a subterranean course for a great distance, it comes within this class if it is shown to be a watercourse in the proper sense of the term. It has also been held that a subterranean stream has a well-defined chamel where its course is marked by certain regetation which wonld grow nowhere except above such subterranean stream. It would seem that the presence of sinkholes or depressions, the structural relations of hard and easily soluble 
rocks, and other geological factors might often be of great importance in helping to establish the existence and direction of subterranean chamels. And while it is not essential that the exact course of a subterranean channel be known in order to establish its existence, a knowledge of that course forms an important addition to the evidence.

It is not sufficient to show that a certain portion of water passes underground from one place to another, since that water, even though it travel in a definite direction, may reach its destination either by percolation through the more or less porous ground or by passage through definite channels. Thus, in a case where the flow of water from a spring was stopped when the water was drained out of a natural basin on higher ground, it was held that the mere fact that the spring was supplied from the basin was insufficient to show that the water flowed from basin to spring in a well-defined channel. In like mamner it is probable that the transmission of coloring matter from one point to another by underground water would hardly be regarded as evidence of the existence of a definite channel, althongh the transmission of particles of material size, such as fragments of wood, might be considered more significant.

Where there is nothing to show that the waters in their subterranean courses are confined to definite and known channels, they are presumed to be transmitted by ordinary percolations through the ground, and so to belong to the second of the two classes of uncierground waters, as defined above.

LAWS RELATING TO UNDERGROUND WATERS OF THE FIRST CLASS.

In the conception of the law all those underground waters which have a definite and known channel are to be dealt with as if they were surface streams, and no distinction is made between such subterranean and surface waters because of their location. Accordingly, the laws applicable to this first class of underground waters are the same as those which apply to streams on the surface of the ground.

It is beyond the limits of this paper to enter into a discussion of the relations of the law to surface waters, but a few of the general principles upon which that law rests may be here referred to in order that the rules governing the use of underground waters of the second class may be better appreciated. Perhaps the most fundamental distinction is that the law recognizes only certain rights in the waters of surface streams (including, as we have seen, underground streams with definite and known chamnels), whereas it arlmits absolute ownership in subterranean percolating waters. The right in the waters of surface streams is, in general, the right to have the water flow through one's land in its natural state, through its accustomed channel, and without material diminution in quantity or deterioration in quality. From this it follows that, in general, one may not 
consume all the water of a stream, although he may appropriate a reasonable portion for his use, provided this right is exercised with due regard to the right of other proprietors above and below him. He may, however, constume what water is required for necessary uses, even if he renders the stream dry. He may not divert a stream so as to cause it to flow onto the land of his neighbor below in a new channel, although he may dirert the stream on his own land, provided he return it to its accustomed channel without material loss before it leaves his property. He may not build a dam which will force the water back upon the land of his neighbor above.

While this is the general attitude of the law toward surface streams and underground waters of the first class, there are many exceptions. Thus, in a Massachusetts decision, it has been held that the proprietor who first builds a dam for reasonable purposes has a right to maintain it, even though it forces the water back upon the land of his neighbor upstream to such an extent as to prevent the latter from having sufficient fall to crect a mill on his land, while his downstream neighbor would not be allowed to build a dam which would raise the water so far as to stop the wheel of the first proprietor's mill. Such a right is generally given by special mill acts. This rule has been repudiated in certain other States, or else made conditional on certain other legal rights. (Pomeroy, pp. 13-15.)

The greatest exceptions, however, are to be found in the Pacific and Rocky Mountain States, where the needs of mining, customs arising in mining camps, etc., have led to the establishment of the law of "prior appropriation," by which the one who first appropriates a stream is entitled to divert, use, and consume such quantity of water from the stream as is necessary for his mining operations; and he becomes absolute owner of such water as is thus appropriated. This doctrine has been extended to all other beneficial purposes for which water is essential, such as milling, mamufacturing, agriculture, urrigation, and municipal purposes. (Pomeroy, pp. 19-20; Goukd, p. 451 et seq.)

\section{UNDERGROUND WATERS OF THE SECOND CLASS.}

(Water passing through the ground below the surface, either without a definite channel or in courses which are unknown.)

LAW'S RELATING TO UNDERGROCND WATERS OF THE SECOND CLASS.

glinerat. principlas.

The relation of the law to underground waters of the second class, or underground waters proper, constitutes the subject of this paper. It is to be remarked at the ontset that the mutual rights and obligations of neighboring proprietors regarding surface streams (includ- 
ing the first rlass of undergromel waters), which have been briefly referred to above, have no application to waters of this second class, which are, or must be presumed to be, orelinary percolations through the general mass of more or less porous ground. The fundamental principle upon which the laws regulating the une of these waters are based is this: That such pereolating subterranean waters are a part of the land itself, and belong absolutely to the proprietor within whose territory they are. The land belongs to the owner, whether it be solid rock, porons ground, entirely earthy matter, or part soil and part water. The percolating waters within his territory are as truly his absolute property as are the rocks, ores, or minerals. Consequently he may take and use such waters as he pleases, although such use may cause damage to his neighbor.

From this it follows that one may withdraw from his soil all the percolating water he desires: and since it is manifestly imposisible to say how much of such water was originally within the limits of his own territory. how much comes into his territory from that of his neighbors, or how much passes from his own territory into that of his neighbors, it is held that he may completely abstract all such waters from his own soil, even though in so doing he also abstracts the water from the soil of neighboring proprietors. In like mauner, one may obstruct or interfere with the natural flow of underground water of this class or change the course of such flow in any way he may choose.

There are sereral conditions which have resulted in the development of such a body of law. The comres of such waters as are embraced in this class being "indefinite and unknown," it has been believed that any other rule wonld hold a man responsible for the preservation of rights which he could not appreciate until after such rights had been violated. Not until his own well was completed could he know that it would abstract the water from his neighbor's well. Sot until his own mine excaration was made could he tell that farming land miles a way would be drained of its water. "One can hardly have rights upon another's land which are imperceptible."

It has also been pointed ont (Tindal, C. J.. in Acton $"$. Bhundell, 12 M. \& W., p. 350) that no one knows what changes these undergromud waters undergo; that perhaps only a day ago the course taken by such waters became what it is to-day. The sinking of any well may completely alter the direction of percolation over a given area: and the proprictor can not be helel responsible for such changes as may benefit or clamage his neightor, but concerning which neither of them can lave any knowledge unt il after the change is effected.

Any other rule, it is argued, would place an unbearable responsibility upon the proprietor. for in the proper use of one's own land it has happened that the waters have been drained from land severa! 
miles away. 'The ordinary work of mining may so drain the water from the soil that destruction of crops, failure of streams, and even care-ins will result at great distances from the mine. To hold the proprietor responsible for such unforeseen results of his legitimate pursuits would necessarily greatly interfere with beneficial occupations of various kinds. Such is the idea expressed by Lewis, C. J., when he says: "No man could rlig a cellar or a well, or build a house on his own land, because these operations necessarily interrupt the filtrations through the earth. Nor could he cut down the forest and clear his land for the purposes of husbandry, because the evaporation which would be caused by exposing the soil to the sun and air would inevitably diminish, to some extent, the supply of water which would otherwise filter through it. He could not even turn a furrow for agricultural purposes, because this would partially produce the same result." (Wheatley «. Baugh, 25 Penn. St., p. 532.)

This whole matter has been stmmed up by one authority in the following words: "The law recognizes no correlative rights in respect to underground waters percolating, oozing, or filtrating through the earth, and this mainly from considerations of public policy-(1) Because the existence, origin, movement, and course of such water's, and the causes which govern and direct their movements are so secret, occult, and concealed that an attempt to arminister any set of legal rules in respect to them would be involved in hopeless uncertainty, and would be, therefore, practically impossible. (2) Becance any such recognition of correlative rights would interfere, to the material detriment of the Commonwealth, with drainage and agriculture, mining, the construction of highways and railroads, with sanitary regulations, building, and the general progress of improvement in works of embellishment and utility." (Brinkerhoff, J., in Frazier ". Brown, 12 Ohio St.. p. 311.)

With the above brief reference to the general principles upon which the law relative to underground waters of the second class is based, attention will now be given to the application of this law to more concrete cases, exceptions to the general rules being noted, and the opinions in accordance with which typical cases have been decided quoted to such an extent as may serve to make the matter clear.

Throughout the following pages it should be borne in mind that "subterranean" or "underground" waters, as here used. refer"s always to the second class of underground waters-those which are, or must be presumed to be, the result of ordinary percolation through the general mass of the ground.

INTERTERENCE WITH WELLS.

It is known that where one well has been successfully supplying water for a time, and then a second well is driven in greater or less 
proxinity to the first, the result may be to diminish the supply of water a vailable from the first well, or even to stop that supply entirely. This matter of "well interference" hats recerved considerable attention from students of the problem, and it is known that the closenesm with which wells may be placed withont expecting serious interfercuce depends npon several factors, anong which is the mamer of their di-position with regard to the direction of the novement of underground waters.

The right of a proprietor to interfere with the supply of his neighbor's well by driving a well on his own land is upheld by an almost unbroken line of legal authority. The only redress which the other has is to sink his well deeper, and the geological conditions may be such that even this will afford him no relief. A proprietor has a perfect right to dig his well and ly means of it to draw off all the water from his own land which would otherwise pass to his neighbor, and also to draw off all the water coming from his neighbor's land, even if the result be to make the neighbor's well entirely dry. Or a proprietor may interfere with his neighbor's well by any other use of his own property, as by digging ditches, excavating mines or quarries, or obstructing in any way the natural flow of underground waters.

Thus, in a case where a mill was run by water raised from a well, and the sinking of a coal pit half a mile distant drew off the supply of water from the well, it was held that the damage to the mill owner was not a legal injury, and that there was no redress for him at law. (Acton c. Blundell, 12 MI. \& W., p. 32t.) In like manner in a cave where the construction of a sewer or drain by one party prevented water from flowing to the well of another and abstracted from the well water which had already found its way there, it was held that the party whose well was thus damaged had no legal redress. (New River Co. $"$ Johnson, 2 El. \& El., pp. 434-446.) "It malkes no diff $(1$ ence whether the damage arise by the water percolating away, so that it ceases to flow along chamnels through which it previously found its way to the spring or well, or whether, having found its way to the spring or well, it ceases to be retained there." (Ballacorkish Mining Co. 1. Dumball, 29 L. T. N. S., p. 659.)

A notable exception to the above rule is presented by certain New Hampshire cares, where it has been held that a proprietor must make such use of his land as is reasonable if he wishes to escapo liability for damage caused to his neighbor's well. The court has expressed its opinion in one such case, as follows: "We do not think it follows * * * that a landowner has the full and unlimited ownership and the aboolute and uncinalified right of control of all water in or upon his land not gathered into naturnl watercourses; for the nonexistence of an absolute right does not conclusively disprove the existence of a qualified right. *** Any interference by one landowner, with 
the natural drainage, injurious to land of another and not reasonable is unjustifiable." (Bartlett, J., in Bassett ". Salisbury Mtg. Co., 43 N. H., pp. 573-574, 576; $82 \mathrm{Am}$. Dec., pp. 180, 185.) - This principle, that the absolute ownership of percolating waters is to be qualified by requiring a reasonable use of wuch water's, has been adhered to in other cases. Thus in an Iowa case (Willis $\iota$. Perry, see L. R. A. 26, p. 12t), a city made several wells and pumped much water from them, thereby depriving a woman of water which she was accustomed to secure from her woll. The city was held liable for damages on the ground that its use of the water was not reasonable. It was also held that the reasonableness of the use did not depend upon the city's needs or wants, but should be determined in view of the number of well owners and their respective wants.

A second exception to the rule is formed by an important California case (Katz $"$. Walkinshaw, 141 Cal, p. 116), referred to in more detail under the heading "Injury to land" (pp. 20-21), where it was held that the owner of one artesian well had no right to withdraw percolating water for the purpose of carrying it to distant lands for sale when such action decreased the supply of his neighbor's well to the irreparable injury of the latter. This decision will probably form a precedent in other irrigation States where artesian water is necessary for agricultural purposes.

Another apparent exception to the general rule is to be found in those cases where a corporation or similar body, having secured control of certain land, makes such use of that land as to damage the well of a neighboring landowner, the corporation being required to pay damages in such cases. This apparent exception is to be reconciled on the ground that the corporation does not secure absolute ownership of the land, but merely purchases certain rights in that land, or else is required by the empowering statute to pay all damages resulting to property not its own. Thus, in a case where excavations by a railload company within its right of way resulted in damage to the well of a neighiboring proprietor the company was held liable for the damage. on the ground that it did not own the land, but had only acquired a special right in the land on the condition of paying all damages which might be thereby occasioned to others. (Parker $v$. Boston and Maine R. R., 3 Cush. (Mass.), pp. 109, 114.) In a case where a corporation was sinking a ditch and well and erecting a pump to get water for its customers, on land held by a private party in fee bnt taken by the corporation uncler a statute, and it was shown that the resilt wonld be to injure the water rights on adjoining land owned by the same private party, an injunction was granted against the corporation (Hart i. Jamaica Pond Aqueduct Co., 133 Mass., p. 488 ) and where a town constructed a sewer upon land taken for that purpose, thereby draining wells fed by percolation through soil on 
land not taken and not adjoining land taken, it was held lialule for the damage on the ground that it was not owner of the land. (Trowbridge ". Brookline, 14t Mass., pp. 139, 141-1+2.)

On the other hand, when it is considered that the corporation or similar body has become absolute owner of the land, the ustal rule applies, and no damages can be recovered in case a well is injured hy the use to which such corporation may choose to put its land. Thus it has been held that a city is not liable for damage resulting from the construction of a sewer. (Elster $\therefore$. Springfield, t9 Ohio St., p. 8.2 et ser.) Where the water was wholly abstracted from a well as a result of the construction of the Washington water tumnel, anthorized by an act of Congress, it was held that the damage was not a legal injury, since the United States had a clear title to the property. (Alexander r. U. S., 25 Ct. Cls., pp. st-97.)

A railroad eompany was not held responsible for injury to a spring in a case where it had acouired the " right of way over and through the land for all purposes connected with the construction, usc, and occupation of its raihay." (Hougan ". Milwaukee and sit. Paul R. R. Co., 35) Iowa, p. 5.58.) It has been held that a railroad company, for the purpose of constructing its road, has the same right to excavate within the limits of its right of way that a private individual has to dig upen his land for any purpose, and that one whose well is rendered dry as a result of such excavation can have no legal redress. (New Albany and salem R. R. Co. 'Pe Peterson, 1t Ind., 112, 11t; 7 Am. Dec., pp. (00, 62.)

In general, then, the rule holds that one who actually own land may make such use of that laud as he may desire, whether such use is reasonable or not being generally held immaterial, and that any damage which such use may caune to a neighbor's well is not a legal injury.

INTERFERENCE WITII SPRINGS.

The rules of law applicable to interference with wells apply in general with equal forec to interference with -prings. It is usmally hold that a proprietor may make stech use of his land ats he desires, although that use may eause the water in his neighloor's spring to diminish or wholly disappear. Thus, in a case where large springs on a landowner"s property were destroyed by excavations made by a metropolitan board of works for a sewer, it was held that no clamages could be collected. (Regina i. Metropolitan Board of Works, 3 B. \& s.. p. 708.) Where a spring was fed solely from pereolating waters from a swamp on wet land around it, and not by any rumning stream, it was helel that no damages contel be recovered against one who diverted the waters by means of a tumel and ditch constructed

IRR 12:-05 $\mathrm{M}-2$ 
on his own land. (So. Pae. R. R. Co. c. Dufour, 95 Cal., p. 615; 30 Pac. Rep., p. 783.)

In a like manner it has been held in a Vermont case that "a grant of a spring does not by implication convey percolating water before it reaches the spring." (Wheelock o. Jacobs, $70 \mathrm{Vt} .$, p. 162.) A spring destroyed by mining operations is not a subject of legal redress in case the ground itself is properly supported. (Gumbert a. Kilgore, 6 Cent. Rep., p. 406.) If the ground itself is improperly supported, however, and a spring is injured in consequence, damages may be collected. In general, also, a city is not responsible because a sewer constructed by it drains away the percolating waters which formerly supplied a spring. (Elster 2 . Springfield, t9 Ohio St., p. 82.)

But there are exceptions to the above general ruling of the courts. It has been held, for instance, that " where a stream, from time immemorial, has flowed through plaintiff"s land in a perceptible current and in a well-defined channel, his right to have such flow continued is not affected by the fact that the source of the stream is a spring on defendant's land." (Pomeroy, p. 176; Chauret e. Hill, 93 Cal., pp. 407-410; 28 Pac. Rep., pp. 1066-106i.)

The question of reasonablenes; of use has been emphasized in some cases, as, for instance, where a person dug a trench and placed a tile pipe in such manner as to abstract percolating water which supplied a spring and to conduct it into a sewer. It was held that the person had no right to collect or divert percolating water for the sole purpose of wasting it. (Stillwater Water Co. c. Farmer, see L. R. A. 60, p. 875.) "Even a railroad corporation armed by law with the eminent domain, and having power to take private property for the construction of its road, is answerable to the owner of a spring for destroying it, although its destruction be caused by excavations on the land of an adjacent proprietor." (Lewis, C. J., in Wheatley r. Baugh, 25 Penn. St., p 533.) As in the case of well interference, discusied above, this last may be only an apparent exception to the rule, and in general is to be reconciled on the ground that the railroad company is not absolute owner of the land, but merely acquires certain rights therein, or is required by statute to pay compensating damages.

INTERFERENCE WITH STREAMS.

Accorling to the law of surface waters a laudowner is entitled to have a surface stream flow through his land in its natural condition without material diminution in quantity. But such streams are often fed largely, either direetly or indirectly, by percolating waters. This brings about an inevitable conflict between the laws of surface and subterranean waters, for acording to the one a proprietor can not do anything which will diminish the volume of the stream flowing through his neighbor's land, while according to the other he has a 
perfect right to the percolating water's which supply that stream, even thongh by using such water's he may diminish the volume of the stream. Conflicting decisions have been the result of such a condition.

The decision of many authorities are on the side of the application of the law relating to sulderranean waterm, aceording to which the one whosuffers as a result of the diminished volume of the stream has no recource againet the one who cauted the damage. Thus, in a cose where a mill which had been propelled for more than sixty years by a stream was retarded lecause the stream was diminished in rolume as a result of the sinking of a well which abstracted a great amount of the percolating water's which fed the stream, it was held that the damage was not a legal injury. (Chasemore $a$ Richards, 7 H. I. Cas., p. 34:): 2 H. \& N., p. 168: : H. \& X., p. 98..) It has likewise been held in California that the fact that a party is entitled to the water of a stream which is fed by a spring ean not prevent the ownex of the land from digging clitches for a uneful purpose and therehy diverting the percolating waters which supply the spring. (So. Pac. R. R. Co.r. Dufour. 95 Cal., pp. (61!-6;20.)

On the contrary, in another case where parties sunk a well on their own property, thins preventing water from pereolating in its natural combe into a strean upon which another"s mills were situated, renulting in damage to the rumning of the mills, it was held that the parties causing the damage were liable for it. (Dickinson $"$. (arand . Tunction Canal (Co., 7 Exch., 1. $28 \%$.) so also it ham been held that " the draining of the undergromnd sources of a surface stream by pumping water from wells to supply a city reservoir render's the city liable to the owner of the land through which the stream naturally flows, although the city is the owner of the l:and on which the wells are located." (Smith r. Brooklyn. 160 N. Y.. p. 35r.) In another case similar to the above, where the defense was made that the defendant had only intercepted muderground waters before they reached the stream, the defense was held to be insufticient. In Nevada it has been held that where a stream is feel by springs. but the water in pascing from such springs to the stream takes a course underground which is not well understood or defined, one can not lawfully cause damage to a prior appropriator on the stream by gaining control of the water from the springs on the ground of a right to take subterranean and percolating waters. (Strait 2 . Brown, 16 Nev., pp. 317-324.)

INJERY TO LAND.

The damage caused by withdrawing subterranean waters is not wholly restricted to interference with the natural conditions of rells. springse and treams. It may happen that the withdrawal of such water's will result in a sinking or caving in of a neighbor's land or in the destruction of his crops. On the general principle that a man is 
absolute owner of the subterranean percolations within his territory and may do as he pleases with them, and because it is held that a man has no legal right to the support of underground water, it has been decided that where a landowner withdraws so much of such water as to cause a subsidence of the land in his neighbor's territory or an injury to his crops, he is not reponsible for the damage. So, also, while a man entitled to take ninerals from a land is required to leave proper support for the surface he may drain the subterranean water froin the ground, even if that results in a subsidence of the surface. (See Gould, p. 565 and subjoined references.)

On the other hand, cases have been decided in the opposite wayas, for example, a certain New York case where it has been held that "The draining of land of a private proprietor by city pumping works which exhaust from all the region thereabouts the natural supply of underground or subsurface water and thus prevent the raising upon it of crops to which the land was and is peculiarly adapted, or destroy such crops after they are grown or partly grown, renders the city liable to him for the damages which he sustains and entitles him to an injunction against a continuance of the wrong." (Forbell e. N. Y., 164 N. Y., p. 522.) The statute of incorporation may hold a com?pany responsible for damages in such cases.

A very important case in this connection is that of Katz $a$. Walkinshaw, decided by a California court in 1903. Parties owning land on which were growing trees, shrubs, ete., which were irrigated by percolating artesian water. brought suit to restrain another landowner from withdrawing such percolating artesian water for the purpose of conreying it to distant lands for sale, on the ground that such action diminished the water supply, to the irreparable injury of the trees, shrubs, etc. It was held that the usual rule of common law on the subject of such percolations was not to be regarded as any part of the law of Califormia, where the arid climate brought about conditions totally different from those existing where the rule in question first sprang up. Consequently the decision of the lower court, based on that rule of common law, was reversed, and it was held that-

"Each owner of soil lying in a belt which becomes saturated with percolating water is entitled to a reasonable use thereof on his own land, notwithstanding such reasonable use may interfere with water percolation in his neighbor's soil: but he has no right to injure his neighbors by an unreasonable diversion of the water percolating in the belt for the purpose of sale or carriage to distant lands.

" The owners of artesian wells cunk in the artesian belt of percolating water. the waters of which are necesary for domestic use and irrigation of their lands, on which are glowing trees. * * * etc., are entitled to an injunction to restrain the diversion of the water 
percolating in the artesian belt, by an owner of land situated in the belt, for the purpose of convering the same to distant lands for sale, to the irreparable injury of the plaintiffs." (Katz $"$. Walkinshaw, $1+1$ Cal., p. 116.)

The rule thus established for California is of far-reaching importance, and will probably form a precedent in the other States of the Thest where subterranean waters are necessarily relied on for irrigation purposes.

DAMMING OF TNDERGROL ND WATERS.

Thus far we have been considering only such cases as involved the abstraction of underground water's. It is possible, however, to work damage to a neighbor by so obstructing the natural flow of underground water as to caure it to set back upon a neighbor's land and so flood it. Following the principle that a man may use that which belongs absolutely to hin in any manner he may choose, it has been held that a landowner who olstructs underground waters within his own territory is not liable for any damage which may result to his neighbor. So in Vermont, where the owner of a mill pond raised the height of the water on his own land, thereby causing subterranean waters to set back and flood a neighbor's land, it was held that the owner of the pond was not liable for the damage caused. (Harwood i. Benton, 32 Vt., p. 724.)

On the other hand. in a similar case in New Hampshire, an opposite decision was rendered. (Bassett v. Salisbury Mfg. Co.. 43 N. H., p. 569.) Where a miner stops up the axit from his mine into a lower mine, thereby causing the water to rise in the upper mine until it flows over into a neighbor"s mine, he is not liable for the resulting damage. In some cases, however. an injunction will be granted against the one abont to cause such damage. (Gould, pp. 572-573 and references.) And if one owner removes barriers by trespass, as by extending his works into his neighlor's mine, he is required to protect that mine against inundation. unless he has already been proceeded against for the trespass, and recovery had against him for it. (Gould, pp. 5T0-571 and references.)

\section{DISPOSAL OF INTER('FP'TED I YDFRGROUND WATERS.}

While a landlowner is entitled to withlraw from his soil all the water he desires, even to the point of alstracting all the water from his own and his neighbor's land. haring onee intercepted such water for his use, he is responsible for the disposal of the same without damage to his neighbor. Having once intercepted and appropriated such water, he can not permit it to flow into his neighbor's land and effect damage there, aren if it would have proceeded there and effected the clamage had he not intercepted it. So a mine owner, 
while he has a right to permit the water naturally flowing in his own mine to pass off by gravitation into the mine of his neighbor, providerl his operations are arried on properly, yet will have no right to let such water pass off into the neighbor's mine after he has once rollected or detained it for his own nise.

The application of this rule to ome particular case is of interest as showing the exact distinction made by the law regarding this point. Certain mine owners sunk a shaft on their property which tapped underground waters that formerly found their way into older workings on the sane property, and thence into a neighlor's mine. The orners of the first property then made a borehole in the bottom of the shaft for the express purpose of letting off the water into the older workings. whence it percolated into the veighbor's mine precisely as before. The cont decided that the owners of the shaft had appropriated the water, and were therefore responsible for any further damage caused by its flowing into the neighbor's nine. This seemed to be in accordance with the principle ontlined above. But the case was appealed, and the former decision was reversed on the ground that the water in the shaft had not been. appropriated at all, but merely altered in its course without even adding to the amount flowing into the neighbor's mine, or changing the time of its getting there. (Went Comberland Iron Co. $\therefore$ Kenyon, 6 Ch. D.. p. 7 73; 11 Ch. D.. p. 782.$)$ In New Hampshire it has been held that a landowner's right to alter the course of such waters is restricted to what is necessary in the reasonalble use of his own property. (Gould, p. 558 and references.) In case undergronthd water reaches the surface through an artesian well, the owner of the woll may be prevented from allowing the water to flow into the streets of a city. (Skaggs $\therefore$. Martinsrille, 140 Ind., p. 476.) But in a case where water from an artesian well was allowed to flow into a natural watercourse which was "the only practicalle outlet for the flow from such well." the owner of the well was held not liable to injunction. (Barnard e. Shirley, 135 Ind., p. 5ti.)

ARtifictal, PRODUCTION OF PERCOLATION.

While it has been held legal for a man to alsstract percolating waters which are on their way to a strean or spring, or to a neighbor"s well. and while he may even cause the water already in his neighlor"s well to percolate out of it toward and into his orm well (see preceding paragraphs). it has been hele unlawful for him to constrnet a well or other structure near a ruming stream, and thus cause currents of percolating waters to develop, which would abstract water from such stream. There is thum a distinct difference between the right to take undergromend water before it reaches surface streams, 
springs, etc.. and the right to alstract water which is already a part of those surface accummlations. And since it is a principle of law that a man hats no right to do indirectly that which he is not allowed to do directly, he can not take water from his neighbor's spring or stream by placing a drain or well only a few feet a way, and thns letling such water run into his drain or well, when he is not allowed to take that water off clirectly by means of a pipe or ditch. As has been stated by one authority. " If you can not get at the muderground water without touching the water in a lefined surface channel I think you can not get at it at all." (Eord Hatherly, L. C.. in Grand Junction Canal Co. '. Shugar. L. R., (; Ch., p. 48s.) Thus in a case where one proprietor constructed a drain close to a surface stream, with the result that the drain drew off the water flowing in the stream, to the damage of a neighbor, an injunction was granted prerenting the unlawful act. (Grand Junction Canal Co. r. Shugar, L. R., 6 Ch., p. 483.) So also in a Massachusetts case it was held that "a person can not draw water from a pond by percolation if he has no right to draw it therefrom directly." (Proprietors of Mills $v$. Braintree Water Supply Co., 140 Mass, p. 478.)

It will readily appear that some difficulty must frequently be found in determining whether or not the artificial structure actnally results in the abstraction of water from a surface stream or other body of surface water. The mere proximity of a well to a stream, for instance, does not prove abstraction. Neither does the diminution of water in the stream, since the well may only secure percolating water which has not yet reached the stream. The farther the well is removed from the stream, the more difficult will it be to satisfactorily establish the fact of abstraction. The party that complains of abstraction has all the burden of this proof, and must fully establish the fact that the well or other structure cloes draw off water from the surface ac'umnlation before the one causing the damage will be held responsible.

ARTIFICIALIT INCREASED PERCOLATION.

It often happens that the natural percolation of a portion of soil is locally increased by various artificial means, as by the pressure of large amounts of water collected in a reservoir, or the sinking and cracking of the surface above mine excavations, thereby admitting water which would otherwise flow off into surface streams. The tendency of the law is to regard this as a "nomnatural "use of the land, and to hold the land owner responsible for any damage he may cause. In Pennsylvania a mine orrner is required to leave proper support for the surface of the gromel above his mine, and if he fails to do this, and the surface of the gromd sinks and eracks as a result, 
Jetting surface waters flow into his mine and from there percolate into the mine of his neighlor. he is liable for any resulting damage. (Gould. p. 5re, footnote.) But in another case where a mine owner so disturbed the soil above his workings as to produce fissures in it. which let the matural rainfall on the surface pass into his mine and thence by gravitation into his noighlor's mine, the mine owner causing the damige was not held liahle. (Wilson ". Waddell, 2 App. (as., p. (5).)

In a certain case a reservoir was constructed for accumulating water, and the contractor failerl to provide sufficient support to resist the pressure of the water in eertain old whafts which communicated with old coal workings, the existence of which was then unknown to the owners of the reservoir or any of those in their employ. The result was that the weight of the water caused it to break throngh the shafts, whence it pasiced through the old coal workings into a neighbor"s mine. No negligence on the part of the owner's of the reservoir appearing, it was held that they were not liable for the injury. This decision, howerer, was reversed in the higher courts, and the orners were held lialle for the damage caused, since "foreign water had been sent down upon the plaintiffs.s. and the defentant's lack of knowledge thus became immaterial." It was held that "the person who, for his own purposen, brings on his land and collects and keeps there anything likely to do mischief if it escapes, must keep it in at his peril, and if he does not do so, is prima facie answerable for all damage which is the natural consequence of its escape." (Rylands ". Fleteher, L. R., 3 H. L., pp. 330, 339, etc.) This principle has since been applied to "injuries resulting to auljoining land from the percolation of the waters of an artificial reservoir or canal through the soil: to water allowed to collect in a cellar and to percolate into the plaintiff"s cellar or well arljoining: to dampness cansed in the plaintiff's house by an artificial deposit near by of spongy soil and clay." (Gould, pp. 57t, 575.) In a number of the States the above principle is modified to the extent that in order to hold the party liable for damage caused it must be shown that he was guilty of negligence. The principle does not apply in cases where the artificial areumulation of water was for the mutual benefit of both parties to the suit: nor where the acermulation was made for public purposes under express authority of a statute, no negligence being proven; nor where the accumulation was not made by the landowner intentionally and for his own benefit, as in the case where a house was destroyed ly fire. and water collected in the uncovered cellar, thence flowing against the walls of an adjoining house buik after the first house was destroyed. (Gould, p1). 575-576, and refer(nces.) In such eases no damages are recoverable. 


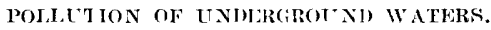

The fact that a man has absolute right to the underground waters within his territory, and may abstract those waters entirely. even to the point of draining his neighbor"s land, does not give him the right to poison or foul those waters and allow them to pass into his neighbor's land in such condition. Such an act is illegal, and he who causes the damage is generally held liable eren if he is not guilty of negligence, "he whose filth it is heing required to keep it on his premises at his peril." This is the principle laid down in the leatling case of Rylands ". Fletcher, cited above. A marked distinction is drawn between the right to lise all the underground water and so prevent its use by a neighbor, and the right to poison or contaminate that water so that when it does reach that neighbor it is unfit for noce.

In a case where casks of oil stored in a warehouse leaked so that the oil entered the ground and indirectly polluted a neighboring spring. the owners of the warehouse were held liable for the damage although they were ignorant of the fact that the oil was affecting the spring. (Kinnaird a. Standard (Oil Co., s. Ky., p. 468.) So in a case where a man permitted sewage to flow into his neighbor's well, he was held liable for the damage, the opinion being given that "The right to foul water is not the same as the right to get it; and in ny opinion does not depend on the same principles. * * * the law of nuisance i, not based "xchnsely on rights of property." (Ballard ". Tomlinson, 29) (Ch. Div.. pp. 11.5, 126.)

In setting forth this same principle it has been said: " It does not follow that becaline I have a right to nte a thing on my own land I may law fully send it into my neighbor"s premises in a condition to work an injury to him. * * * The Aneriean cases. therefore, while recognizing to its fullest extent the right of every landowner to use, detain, and even totally abstract all the underground pereolating water, *** yet quite agree with the decision *** $*$ that he is liable for corrupting it and thus cansing an injury to the well of an adjoining owner. *** The true cause of action *** is not exactly that the defendant contaninaterl undergromnd percolating water, bit that he allowed his impure servage to escape from his premises to the plaintiff's, and the circumstances that it reached there by underground percolation instead of by a

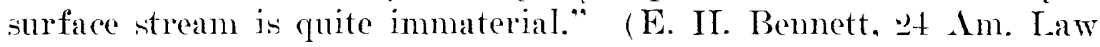
Reg., pp. $638,(6+0$.

In cares where substances from the rorks of a gas company have percolated into the soil, resulting in injury to a neighbor's well, the company hats been held liable for the lamage. In a case where it was shown that other things hesirles the proape of gas into the water of a well contributed to make it unfit for use, it was held that the 
gas company was liable for damage to the water, although the fact that there were other somres of corruption might be shown in mitigation of the amount of damage recoverable. (Sherman $A$. Fall River Iron Works Co., 5. Alleu (Mass.), p. 213.)

So when filthy water from a vault percolates through the ground and injures the cellar and well of a neighboring proprietor, the party who maintains the vault is liable for the damage. (Ball $c$. Nye, go Mass., p. 582.) Likewise where poorly constructed sewers permit filth to percolate from them into the cellars of aljoining premises the one who maintains such sewer is liable for resulting damages, "eren if he is the owner of the premises into which the filth pereolated, and the parties complaining were his own tenants." (Alston ". Grant, 3 El. and Bl., p. 128.)

In a ease where a pertion polluted his own well with sewage, and the contaminated water percolated into a neighbor's well, it was claimed that the party causing the damage was not liable, since the neighbor whose well was injured secured the water from that well by artificial means-i. a., ly pmuning. The comt held the party liable for the clamage he caused, however; Brett, M. R., stating that "The plaintiff, if he has a right to nse anything in nature, has a right to exercise that use by all the skill and invention of which a man is capable, and it reems to me that as long as the plaintiff uses only lawful means as against his neighbor, however ingenious or however artificial those means may be, his right to appropriate the common source is not diminished because he used the most artificial or most ingenious methork." (Ballard ". Tomlinson, 29 Ch. Div., p. 122.)

In cases where it can be shown that the acts of another will result in a pollution of underground waters, the courts will grant injunstions to prevent such injurv. Thus a perpetual injunction was granted to restrain a party from allowing unclean refuse matter to pass from his manufactories into an old pit on his own land, since it percolated thence into a neighbor's colliery. (Turner i. Mirfield, 34 Beav., p. 390.) In another case a party was prevented by an injunction from using a cesspool through which water percolated into a neighboring well. (Womersley i. Church, 17 L. T. N. S., p. 190.) So alio an injunction will be issted to prevent the establishment of a burial ground, when it can be shown that the burial of the deat there will endanger life or health by corrupting the surrounding atmosphere or the water of springs or wells. (Clark a. Lawrence, (f Jones"s Eq. (N. C.), p. 83; is Am. Dec., p. 241.) There must le elear proof of probable injury. however. It has elsewhere been held that eities have absolute authority to establish cemeteries, and cliscretion to judge of their necessity. (Greencastle i. IIacelett, 23 Fnd.. p. 186.) In a case where a party was about to erect a privy on his own lot, alout 
is feet from his neighlor's home and cellar, and lesis than 20 feet from his well, the completion of the priry was prevented by injunction. The court, quoting another authority, said: "Privies are regarded as prima facie nuisances, and although necessary and indispen ${ }^{\wedge}$ ible in connection with the use of property for the ordinary purposes of habitation, yet if they are built or allowed to remain in such a condition as to annoy others in the proper enjoyment of their property by reason either of the noisome smells that arise therefrom or by the escape of filthy matter therefrom upon the premises of another, or $\varsigma_{0}$ as to corrupt the water of a well or spring, they are nuisances in fact." ( W'ahle $i$ Reinbach, 76 Ill., pp. 322, 326.)

There are a few exceptions to the above rules, howerer, it being held in sereral cases that the party causing the pollution of underground water is not liable for damage caused to a neighboring proprietor unless guilty of negligence or malice. In one such case the court observes, "If withdrawing the water from one's well by an excavation on adjoining lands will give no right of action, it is difficult to understand how corrupting its water's by a proper use of the adjoining premises can be actionable, when there is no actual intent to injure and no negligence. 'The one act destroys the well, and the other does no more; the injury is the same in kind and degree in the two cases." (Cooley, J., in ITpjohn e. Richland Township, ti Mich.. pp. 549, 5.50.)

So in a case where the operator of gas works placed obnoxious substances near a neighboring property, and portions of these substances were washed along the surface into the neighbor's well, and other portions penetrated iuto the ground, thus polluting the subterranean currents which supplied the well, the court held that while the operator was liable for the surface pollutions, he was not liable for any damage to the well resulting from the pollution of underground currents of water unless he acted malicionsly. (Brown $i$. Illius, 27 Conn., p. s-t.) In another case the party polluting underground streams whose channels and courses were unknown and undefined, was held not to be responsible for the clamage caused. (Dillon 1. Arme ()il Co.. 49 Hun. (N. Y.), p. 565.) In this ease a distinction was made between contaminating a subterranean stream whose channel and course were undefined and unknown, and contamination by percolation or soaking. This, also, seems contrary to the general rule of law, which makes no distinction between ordinary percolating waters, and such underground streams as have channels and conrses which ar inlefinite and unknown.

In a case where a party sunk an artesian well upon his own land and used the water to bathe the patients in a sanitarium or hospital erected by him on his premises, and then allowed the polluted water to flow into a natural watercourse, which was the only practicable out-

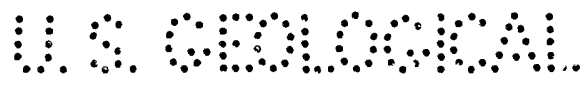


let for the flow from the well, the party was held not to be liable for the resulting damages, providing he was free from nogligenes and malice and used due care to avoid injury to his neighbors. (Barmard ". Shirley. 135 Ind.. p. 5ti.) This decision seems contrary to the general ruling of the conrts in a twofold way, since it is generally held that one who intercepts and uses underground waters is responsible for their future course (pp. $21-2.2)$, and the pollution of waters is usually illegal whether or not there be malice or negligence.

The principle upon which the decisions in these exceptional cases is based seems to be that a man'is obligations to preserve the purity of underground waters is limited to the reasonable and proper use of such waters, without negligence or malice on his part. According to this principle, any damage to a neighbor which is necessary and unavoidable, or not sufficiently obvious to have been foreseen, resulting from a landowner"s proper and reasonable use of his land, is not held to be a legal injury.

Having now outlined the general relations of the law to the abstraction, diversion, and interruption of underground waters, and to the pollution of the same, it remains to be pointed out in what ways the general rules are modified, if at all, (1) by the motive with which the acts complained of were done: (־) by definite agreements between the parties respecting the use of the underground waters; (3) by prescription, or the long-continued use and enjoyment of such waters.

EFFECT OF MOTIVE.

Although an act may in itself be perfectly legal-as, for instance, the abstraction of underground waters from the soil, even to the point of rendering dry a neighbor's well, is generally held to be-it might be considered that a person who exercised such right with the malicious and evil intention of hurting his neighbor would be guilty of a legal injury. This question as to the effect of motive has given rise to a number of conflicting opinions.

So far as the pollution of mulerground waters is concerned there is little disagreement among authorities, it being generally held that, however innocently the contamination is effected, the party cansing the damage is none the less liable for it. As we have seen, howerer, there are cases in which the party was not held responsible, provided he was guilty of no negligence and entertained no malicions motives.

In cases involving the abstraction or diversion of underground water's with malicions intent to injure a neighbor opinions have been more conflicting. The weight of authority, especially in more recent cases, is to the effect that the motive is immaterial, according to the principal that the law must deal with outward acts and not with inward motives. "When the use whieh a landowner makes of his property is lawful in itself, the law will not take cognizance of the motive

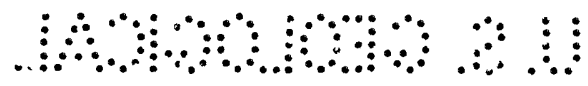


which prompts the nse, even where it results in damage to another." (Enc., 434.) So it has been held that while "malicious motives make a bad act worse, * * * they can not make that a wrong which in its own essence is lawful." (Black. J., in Jenkins ". Fowler, 24 Penn. St.. p. 310.) According to another authority, " Bad motives in doing an act which violates no legal right of another can not make the act a ground of action." (T. R. Strong, J.. in Pickard 1. Collins, 23 Barb. (N. Y.), p. 459.) In another case the court observes, "As an act unlawful in itself resulting in injury to another. whatever may have been the motive with which it wan dlone, is none the less the subject of legal redress, so the act done, to wit, the using of one's own property, being lawful in itself, the motive with which it was done-whatever it may be as a matter of conscience-is in law a matter of indifference." (Brinkerhoff, J., in Frazier ¿ Brown, 12 Ohio St., p. 31131․) So, also, in another case, " We have not given any attention to the alleged motives of the defendant. Their motives are immaterial. The question is only as to their rights." (Rodman, J., in Porter ". Durham, $7+$ N. C., p. 780.)

In accordance with the above opinions was the decision rendered in the following case: A landowner possessed a mineral spring unrounded by an artificial embankment. His neighbor dug a well on lis own land, striking a rein of mineral water, evidently intimately connected with the adjacent mineral mpring. and the water from this vein rose high enough to be conducted by pipes to the neighbor's bath house. Then the owner of the spring. for no purpone beneficial to himself and simply to divert the water from his neighbor's well, lowered the embankments about the spring. thereby cutting off the supply of water from the neighbor'- well. It was held that the owner of the spring was not liable, the question of motive not affecting his legal right. (Phelps 1 . Nowlen, T2 N. Y., p. 39.) As stated by another authority, " It in generally held that no action will lie against one for acts done upon his own land, in the exercise of his rights of ownership, whatever the motive, if they merely deprive another of advanlages or cause a loss to him, without riolating any legal right : that is, the motive in such cases is immaterial." (Wells, J.. in Walker r. Cronin. 107 Mass. p. j(it.)

In striking contrast to the above are cases in which the authorities consider the motive as an important factor in the case. Thus it has been held that " neither the civil law nor the conmon law permits : man to be deprived of a well or spring or stream of water for the mere gratification of malice." (Lewis, C. J., in Wheatley ". Baugh, 25) Pemn. st., p. 533.) In another (a) the opinon was given: " (orellnarily a landowner may dig a well upon his own land, oven themgh, hy percolation, it draws the water from his neighlor: land. or erent his well; but it would present a very different question if the well was 
dug by him with the express purpone of transferring the water in his neighbor's spring or well to his own. and knowing that this would be the result." (Bellows, C. J., in Swett ". Cutts, 50 N. H., pp. 446-447.)

Acording to another authority, "While a man has wo right to protection against competition, he has a right to be free from malicious and wanton interference, disturbance, and annoyance." (Barrows, J., in Chesley ' '. King, $7+$ Me., p. 175.)

FFFECT OF GRANT OR AGREEMENT.

It seens to be well established in the courts that where one party zrants certain water rights to another or makes an agreement with him regarding rights to underground waters, the parties shall be bound by the terms of the grant or agreement, and not by the rules of law applicable to underground waters in general. Thus, while in general a man may lawfully dig a well on his own land, even though he thereby drain off the watcre from his neighbor's well or spring, he can not do so if his act violates a grant or an agreement with that neighbor. But in cases where the act complained of does not violate any express provision of the grant or agreement, the usual rules of law are considered to apply. The following cases serve to illustrate the several phases of the question.

I party granted the surface of his land to another. but reserved the mine; below. In the operation of his mines the water was all drained from the surface, thus damaging the one to whom he had made the grant. He was not held to be responsible for the clamage, since he had made no express agreement regarding such waters. (Ballacorkish Mining Co. ‘. Harrison, L. R., .5 P. C., p. 49.) And where a man sells a well to another, and then by digging another well or in some other manner prevents percolating water from reaching the well he has sold, he is not liable for the damage if the sale of the well does not carry with it a guarantee of a regular supply of water. (Fould, p. 562, and references.) So, also, with a spring. "A grant of a "certain spring or fountain of water" does not deprive the owner of the land of the right of properly draining his land to make it productive, even though in some unknown mole the drainage of the land may affect his supply of water." (Ene., p. 431. footnote and references.) In a case where one party purchased land from another with the agreement that the other shonkl have a right to conduct water from a spring on the land thus sold to his adjoining property, and then the purchaser ding a well on the land which he had bought, destroying the spring from which he had agreed to let the other conduct water, it was held that the purchaser was not responsible for the damage, since the agreement rirl not entitle the other to an uninterrupted flow of the water. (Enc., p. 431, footnote and references.) Where one party granted another the right to draw water from a certain 
well by a pipe laid in the ground, he was not prevented from digging another well or reservoir on his own land, thereby diverting the water which formerly pereolated into the well. (1)avis ". Spandeng, 15t Mass.e p. 431.) In cases where the effect of the grant is to make the parties to it practically adjacent owner's, the usual rules of law apply.

But where the terms of the grant or agreement plainly secure a regular supply of water to the one to whom such grant is made, one who interferes with underground waters so as to diminish or interrupt the supply will be held liable. Thus, in a case where a proprietor granted to a manufactory situated on his land the use of water conducted to the factory from springs on his land, and " covenanted to warrant and defend the granted premises against himself and all other yerons." and then withdrew the supply from such springs, he was held liable for the damage. (Johnstown Cheese Mfg. Co. r. Veghte, tig N. Y., p. 16.)

In another case a man owned two adjoining farms, on one of which was a spring from which water was conclucted in pipes to the barnyard of the other. IIe sold this latter farm with appurtenances, but withont special mention of spring and pipes. Then he dug a well near the spring, thereby lowering the water in the latter till it failed to flow through the pipen. It was held that he could be restrained from using the well causing the injury on the ground that the uninterrupted flow of water was essential to the full enjoyment of the estate conveyed. (Paine 1. Chandler, $18+$ N. Y., p. 38.5.) This appears to be a depart ure from the general rule, unless" "appurtenances" is interpreted as including the waters percolating into the spring on adjacent land, for in cases where the opposite decision was rendered, as noted above, the uninterrupted flow of the water was even more certainly essential to the full enjorment of the well or spring convered.

When the privilege of taking water from springs of a certain locality is granted the waters (an only be taken where they naturally come to the surface, not from wolls or other orifices where the water does not come to the sirfiace. (Ene., p. 431 , footnote and references.)

1 grant of a well or spring carries with it the right to the land inmerliately oecupied by such well or spring. So the well is held to include "the orifice reaching down to the water. the whole opening in the earth before it is stoned, the stone laid in the wall, and the water therein." There a spring was set apart and separated from other land so as to extend three rods each way from the central portion corered by water, the word "spring" in a deed was held to include this land. (Gould, p. 56:3 and references.)

EFFECT OF PRESCRIPTION.

In law the use and enjoyment of things " from time immemorial" is held to give a legal right to certain of the things thus used and 
enjored. This is known as the right arising from "prescription." but this right can not exist with regard to underground waters, it being held that the owner of land can not acquire by prescription the right to receive percolations through the land of another. This is clearly set forth in the following opinion: "The doctrine of prescription, presumption of grant from lapse of time, can have no proper application to the question. (1) Because the party against whom the doctrine will have to be applied could not be reasonably required to enter his caveat against the appropriation of a thing so hidden and obscure as is percolating underground water; and (2) because the appropriation of such water by an adjoining proprietor is not an infringement of his rights, so as to become the subject of legal redress, until such time as he himself has occasion to appropriate them." (Brinkerhoff, J., in Frazier v. Brown, 12 Ohio St., p. 311.)

\section{SUMMARY AND CONCLUSIONS.}

In summing up the generalities of the relation of the law to underground water's it is to be noted that wherever a subterranean stream can be shown to have a defined and known channel it is considered subject to the same rules of law that apply to surface streams; but where subterramean streams have channels which are indefinite and unknown, or where subterranean waters percolate through the ground independent of channels, different rules of law are applicakle. Regarding the laws controlling the use of this second class of underground waters a number of points have been noted.

It has been seen that, according to a large number of decisions, a man is entitled to practically absolute control of such underground waters in his own land, but that some authorities limit him to a reasonable and proper use of such waters. The destruction of a well or spring as a result of an adjacent landowner's excavating a well, spring, cellar, mine, or ditch upon his own land is generally held to be a damage for which there is no remerly at law. But some authorities hold that in order to escape liability for such damage the party causing it must have made such use of his land as is reasonable and proper. Where the damage is caused by a corporation, as by a railroad company excaratiog on its right of way, damages are in general recoverable, although it has been held in some cases that such a company is no more liable for damage caused by excavations on its right of way than is a private citizen for damage resulting from excarating on his own land. It is to be noted that in the irrigation States of the West the cases are likely to be decided on different principles from those governing decisions in the East. To this effect is the California decision that "the common law rule that pereolating water belongs unqualifiedly to the owner of the soil, and that he has the 
absolute right to extract and sell it, is not applicable to the conditions existing in a large part of this state, where artificial irrigation is essential to agriculture, and artesian wells in percolating belts are necessarily used for that purpose." (Katz c. Walkinshaw, 141 Cal., p. 116.)

Where surface streams; are injured by a loss in volume due to the fact that a well or other excaration on a neighbor's land intercepts the percolating waters supplying the stream, it is generally held that there is no redress for the damage, but. some authorities hold that the one causing the damage is responsible for it. If a'man makes a well or other excavation near a stream or other body of surface water. and thereby extracts water which has already become part of a surface accumulation, he is responsible for the resulting damage.

Where land is injured by the withdrawal of the undergroumd water through a neighbor"s well or other excavation, so that the land fails 10 support crops, or sinks and crackss. it is usually maintained that there in no remedy at law, although there are exceptions to this ruling. Where the obstruction of underground water's made such waters set back and orerflow a neighbor s land, it was held in one case that the party causing the damage was not liable, while the opposite decision was rendered in another and simitar case.

One who interepts undereground water's ant appropriates them tor his own benefit is in general responsible for any danage they maly ause thereafter, aren if the tamage is the same as the water's would naturally have caused if not intercepted. But an opposite decision has been rendered in at least one such case. One who merely alter's the course of percolating waters and does not appropriate them for une is not generally responsible. In one state, however, it is held that the right to alter the course of unterground waters is restricted to what is necessary in the reasonable use of property.

Any one who artificially increases the natural amome of pereolation is, arcording to some authorities, responsible for the resulting damage, but other's hold that unless the damage is the result of negligence or malice no legal redress can be obtained.

The pollution of underground water's is generall. held to be illegal, whatever the circumstances attending such polhution. But a few anthorities maintain that such pollution is not illegal unless there is pridence of negligence or malice.

In case any of the foregoing arts, which are legal in and of themselves, is dome with the express purpose of injuring a neighbor, some anthorities hold that the one committing such an act with malicions motive is responsible for the damage he aruses. But other's and perhaps the majority. take the position that such an one is not liable. since the motive is immaterial.

IRR $122-05 \mathrm{M}-3$ 
Where any of the foregoing acts, in themselves legal, violates the express terms of a grant or an agreement, the act becomes illegal.

No special right to molerground waters can be acquired by long continued use and enjoyment of the same.

Such a review affords ground for careful reflection concerning the laws of underground water. (Bne is impressed with the great lack of agreement among authorities respecting many of the points at issue. The law of waters in general is an intricate problem, and it is not to be expected that the unsatisfactory feature referred to will ever.be wholly eradicated. It is probable, however, that a better appreciation of some of the facts established within recent years by various investigations into subterranean conditions will result in more harmonious opinions, and make possible a more just administration of the law's in question.

The great lack of agreement among authorities on questions pertaining to underground waters is due in part to the nature of the problems involved. There is so much that is uncertain and indefinite in the behavior of waters hidden beneath the surface that more or less uneertainty must unavoidably attach to the laws respecting them. Perhaps the only practicable remedy is to be found in the removal, so far as it is possible, of the uncertainty and indefiniteness by an extension of our knowledge of subterranean conditions. Marked arlvances have already been made in this direction, and many questions may be settled to-day far more equitably than was possible a few years ago.

It is beliered that a second and very important reason for the unsatisfactory condition of the law relating to underground waters is to be found in the fact that the state of our knowledge regarding such waters is now in advance of the general ruling of the conts on some of the questions involved. The earlier legal decisions and authoritative opinions were made at a time when rery little was known regarding that which was beneath the surface. The fundamental conception upon which many of the opinions rest is that we are ignorant of the conditions controlling waters hidden from our view. Since that time the progress of geological science has wrested from the unknown many things regarding undergromnd waters and firmly established them in the realms of known fact. These things: should serve to make possible a more equitable settlement of controversies involving right to unlerground waters; and where a decision is controlled by opinions rendered in former cases, and not made with due regard to the present knowledge respecting subterranean conditions, it does not seem that a just settlement of the controversy can be reacherl.

That the earlier decisions and opinions serve as a guide for later 
decisions is a fact known to those who are familiar with onr legal procedure, and is evident on reading the decisions handed down in the various cases. Even where a certain judge was convinced from the eridence that the older decisions were manifestly wrong when applied to the case under consideration, the additional facts arailable in that case having thrown new light on the problem involved, nevertheless he felt compelled to decide in accordance with established precedents and against what he believed to be the right. (Collins e. Chartiers V. Gas Co., 131 Penn. St., pp. 159-160.) The higher courts in this instance reversed his decision. The case serves to call attention to the importance of emphasizing the influence which the ever-increasing knowledge concerning underground waters may and should have in governing legal decisions. The need of acquainting the public with such facts as are ascertained by the drilling of wells, the excarating of mines, and the investigations of public or private surveys is evident.

This point has been well appreciated by Mr. Justice Mitchell, who observed, "Geology is a progressive, and now, in many respects, a practical science, and, as truly remarked by the learned judge below, in his opinion on the motion for a new trial. "Since the decision in Acton $\therefore$. Bhundell and Wheatley $\because$. Baugh. probably more deep wells have been drilled in western Pennsylrania than had previously been dug in the entire earth in all time. And that which was then held to be necessarily unknown and merely speculative, as to the flow of water underground, has been, by experience in wheh cases as this, redncer almost to a certainty.' If this is the state of knowledge at the present day; if the existence of a stratum of clear water, and its flow into wells and springs of the vicinity, and the existence of a separate and deeper stratum of salt water, which is likely to rise and mingle with the freshl, when penetrated in boring for oil or gas, are known. and the means of preventing the mixing are available at reasonable expense, then, clearly, it would be a violation of the living spirit of the law not to recognize the change, and apply the settled and immutable principles of right to the altered conditions of fact." (Collins r. Chartier's V. Gas Co., 131 Penn. St., pp. 159-160.)

In many cases the original lack of knowledge, which was the efficient reavon for the ruling of the law has already disappeared. It is sufficient for the present purpose to call attention to a few concrete instances. Thus, as stated by one anthority, it has been held "that injury to springs, wells, etc., supplied by mere percolation, was not actionable, and the reason has always been the same, that the damage could not be foreseen or aroided." The are now in possession of definite knowlerlge concerning the amount, rate, and direction of flow of underground water in certain cases, as well as concerning the thickness of the water-bearing stratum, its depth below the surface, 
and other valuable facts. In such eases it may often be possible to foretell with certainty that a given well or excavation will affect the silpply of a neighloring well or spring. The damage may, therefore, be certainly foreseen. It may also be possible to show how a different position of the well would lecrease the interference, or provent it entirely, and thus avoid the damage to a greater or less extent. The damage may, therefore, be aroided in eases. The statutes of South Dakota and one or two other States recognize this possibility to foresee and prevent well interference, and make due provision for it.

So also it is now possible, in many cases, to predict with certainty what course would be taken by polluting substances carried by underground percolations, and so foretell which wells or springs would probably suffer and which would not. By noting the inclination and chanacter of the rocks it has been possible to show that the polluted waters fiom a cespool on one side of a hill would without doubt be carried down the slope of the beds. through the hill, to a spring an the opposite sidle. The comse of such water's may in eases be demon:strated experimentally.

In one of the leading cases on this subject it was argned tha. "there in an abolute impossibility for anyone to know what are the underground currents, where they begin, what they produce, and in what direction they rum, and consequently an abolnte impossibility of knowing what are the rights in relation to them." To-day we do know, in mumerons cases, what the underground currents are, where they begin, in what direction they run, and even at what rate they progresis. of what volume they are, and what in general are their vertical and lateral extents. So we might now say that there is a posibility of knowing and defining what are the rights in relation to them.

According to some authorities percolating waters are to be conpared with the rocks and minerals contained in the gromel, and absolute ownership accorded the landowner on the same principle in both cases. Such is the iclea expresised by Joseph K. Angell in his treatise on The Law of Water Courses (ath edition, pp. 110-111). in the following words: . *** in contemplation of law, land alway's extends downward an well as upward; so that whatever is in a direct line between the surface of any land and the center of the earth belongs to the owner of the surface. It would consequently seem to follow that whether what is subterranean be solid rocks, mines, or porous soil. or salt springs, or part land and part water, the person who owns the surface may dig therein and apply all that is there found to his own purposes ad libitum."

It seems to me that this principle in essentially erroneous. We now know that percolating water's may and usually do possess a 
refinite rourse, that in certain ases they enter the gromel at given localities which may often be determined with acemracy, that they often have a certain flow with a fairly definite velocity year in and year out, and that they exist at certain depths below the surface. It is evident, then, that such water's are not to be compared with rocks and minerals which are, as such, stationary in the soil where tliey occur until removed by some external power; but that they are better to be compared with those water's upon the surface which pass into the land from one elirection and ont of it in another: and which are not regarded as the absolute property of the landowner. Furthermore, the removal of the rocks and soil from the land of one owner does not take away the rock' and soil belonging to his neighbor: while the removal of percolating water from the land of one owner does result in taking away the percolating water belonging to that neighbor. In other words, there certainly is a common interest in the water which does not exist in the case of the rocks and soil. As has been well said by Justice Temple, "It is obvious' at once that the analogy between the right to remove sand and gravel from land for sale and to remove and sell percolating water is not perfect. If we suppose a saturated plain, one may remove and sell the sand and gravel from his land withont alfecting or diminishing the sand and gravel from the lands of his neighbort. *** But when he drains out and sells the water on his land he draws to his land, and also sells, water which is the property of his neighlbor. *** $*$ * In short, the member's of the community. in the case supposerl, have a common interest in the water. It is neressary for all, and it is an anomaly in the law if one person can, for his individual profit, destroy the commmity and render the neighborhood uminhabitable." (Katz 1. Walkinshaw, $1+1$ Cal.. p. 1t0).)

It is believed therefore that absolute ownership of percolating waters can not be properly granted to any landowner on the basis of the principles here considered; lut must be granterl, if at all, on the ground that our ignorance of subterranean conditions, or considerations of public policy, make such a ruling necessary. With the disappearence of the ignorance in question one of the reasons for such a law disappears, and it remains to be seen what provisions of the law, in the light of new facts, are justified by eonsiderations of public policy.

As was pointed ont at the beginning of the discussion of underground waters of the second class, some authorities justify the refusal of the common law to recognize correlative rights in respect to such waters on the ground that "the existence, origin, morement, and course of such waters, and the causes which govern and direct their movements, are so secret, occult, and concealed that an attempt to 
alminister any set of legal rules in respect to them would be involved in hopeless uncertainty, and would be therefore practically impossible." At the present time our knowledge of the workings of underground waters, of their origin, movement, and courses, and of the causes which govern their actions, leaves much less in the realm of the "secret, occult, and concealed." It is possible to define certain rights in these waters, and to protect those rights as well as those in surface waters. As has been recently held by a California court: "The difficulties which the courts will meet in securing persons necessarily using percolating water for irrigation by means of artesian wells, from the infliction of great wrong and injustice by its diversion, if property rights therein are recognized, can not justify the court in abandoning the task as impossible. The courts can protect this particular species of property in water as effectually as water rights of any other description." (Katz $v$. Walkinshaw, 141 (al., p. 116.)

There yet remains much that is uncertain regarding subterranean conditions; but as, in the past, geology has added much to our store of knowledge concerning those conditions, so in the future we may confidently expect a continued increase in the known facts. And with this increase in knowledge we should look toward an increasingly satisfactory adjustment of those controversies which arise concerning subterranean waters. There probably must always be cases in which the subterranean conditions are indefinite or unknown, but the number of such cases will decrease; while it will be possible to adjust a constantly increasing proportion of the cases more equitably than was possilile in the days when practically nothing was known about that which lies hidden beneath the surface of the ground.

The lack of agreement among legal authorities on many of the questions at issue is rather more fortunate than unfortunate in one respect at least, since it bears witness to the uncertain position of the law on the points involved and opens the way nore readily for new knowledge bearing on the problems. Where the court is not bound by a long and unbroken line of legal authority, its decision is more apt to be in accordance with the general principles of right as applied to the present state of knowledge regarding the problem under consideration. More importance will attach to a complete and searching investigation into all the facts of the case in hand, since less will depend upon decisions rendered in similar cases years ago. 


\section{CHA PTER II.}

\section{LEGISLATIVF ACTS AFFECTING INDERGROUND WATERS.}

\section{INTRODUCTION.}

It has been thought advisable to present a brief review of the more important legislation enacted by the different States and Territories on the subject of underground waters. No attempt has been made to gather every reference in State laws to the subject, but it is believed the following summary will give a fairly accurate idea of the extent of such legislation and will furnish the reader with the most important provisions relating directly to the control of waters flowing beneath the surface of the ground.

It will readily appear that most of the legislation on this subject has arisen in connection with the sinking of artesian wells for the purpose of securing underground water for domestic and mechanical purposes, and more especially for irrigation. In some of the Western States, where irrigation is largely dependent on artesian wells, this class of underground waters occupies a prominent place in the State laws.

Much of the legislation on this subject refers only indirectly to the underground water itself, being concerned with the duties of officials in regard to the sinking and controlling of wells, the appropriation of money, and the levying of taxes to provide for the cost of such wells, the rights and duties of those benefited by the water thus secured, and other topies of this general class. Material of this character has been omitted, brief references sometimes being given to the reports where it may be found.

Most of the States having special laws relating to underground waters are given below in alphabetical order, with such reference to their laws as seemed desirable for the purpose of this report.

\section{CALIFORNIA.}

The laws of California provide for the regulation of the use of artesian wells and prohibit the waste of subterranean waters. In an act (I... 1877-78, p. 195), approved in 1878, it is provided (sec. 1) that:

"Any artesian well which is not capped or furnished with such mechanical appliances as will readily and eflectively arrest and prevent the flow of water from such well is hereby declared to be a public nuisance. The owner, tenant, or occupant of the land upon 
which such well is situated who caulses, permits, or suffer's such pultlic nuisance, or suffers or permits it to remain or continue, is guilty of a misdemeanor."

Also (sec. 2) that:

"Any person owning, possessing, or occupying any land upon which is situated an artesian well, who causes, snffers, or permits the water to unnecestivaly flow from such well or to go to waste, is guilty of a misdemeanor."

For the purposes of this act an artesian well is defined (sec. 3) as " any artificial well the waters of which will flow continuously over the surface of the ground adjacent to such well at any season of the year;" and waste is defined (sec. 4) as follows: "The causing, suffering, or permitting the waters flowing from such well to run into any river, creek, or other natural water course or channel, or into any bay, lake, or pond, or into any street, road, highway, or upon the land of any person other than that of the owner of such well, or npon the public lands of the Tnited States or of the State of California, unless it be used thereon for the purposes and in the manner that it may be lawfully used upon the land of the owner of such well: Provided, That this section shall not be so construed as to prevent the use of wuch waters for the proper irrigation of trees standing along or upon the street, road, or highway, or for ornamental ponds, or for the propagation of fish."

A fine of not less than $\$ 10$ or more than $\$ .50$, together with the cost of prosecution, is assessed against those convicted of violating any of the provisions of this act. and the superrisors or roadmasters are smpowered to enter upon the premises where wells complained of are situated, and to institute eriminal action where violation of the prorisions of this act is discorered.

\section{COLORADO.}

The laws of Colorado regulate the use of artesian wells and prohibit the waste of sulhterranean waters in much the same way as the laws of California above cited. Further provisions are made for the keeping of accurate records of the depth and thickness of the different strata penetrated, for determining the legal status of seepane or spring waters, and for the sinking of certain artesian wells.

An act (L.. 1887, p. 52) approved in 1887 provides (secs. 1 and 2) that: "Any artesian well which is not tightly cased, capped, or" furnished with such mechanical appliances as will readily and effectively prevent the flow of water from such well is hereby declared to be a public nuisance. The owner, tenant, or occupant of the land upon which such well is situated, who causes. permits, or suffers such public nuisance, or suffers or permits it to remain or continue. is guilty of a misilemeanor. 
“. Any person owning, postessing. or ocrupying any land upon whidh is situater an altesian well, who causes, suffers, or permits the water to unnecessiarily flow from such well, or to go to waste, is guilty of a misdemeanor."

For the purposes of this act an artesian well is defined much the same as under the California law above cited, except that it is provided that nothing in the act shall apply to water flowing. from mining shafts, and the definition is made to read, "the waters of which, if properly cased, will flow continuously," etc.

Waste is defined as in the California law, with a few minor modifications in the wording, and with the provision that the use of the water for agricultural purposes is allowed in addition to the other uses cummerated above.

A fine of not less than $\$ .50$ nor more than $\$ 300$, together with the cost of prosecution, is assessed against anyone violating any of the provisions of the act. The county commissioners, road overseers, city engineer, or city officers are empowered to investigate and prosecute alleged violations of the act.

It is further provided (sec. 7) that: "Any person boring or causing to be bored an artesian well, shall keep a complete and accurate record of the depth and thickness of the different strata penetrated, and when such well is completed, shall tile such record in the office of the county clerk and recorder of the county within which such well is situated, and immediately transmit a copy of such record to the office of the State engineer. Any person violating the provisions of this section shall be deemed guilty of a mi-demeanor and shall, upon conviction, be fined not less than ten nor more than fifty dollars."

By an act (I., 1889, p. 215). approved in 1889), the rights relating to the use of seepage and spring waters are defined as follows: "All litches now ronstructed or hereafter to be constructed for the pur. pose of ntilizing the waste, seepage, or spring waters of the state shall be governed by the same laws relating to priority of right as those ditches constructer for the purpose of utilizing the water of rumning streams: Prorided, That the person upon whose land the seepage or spring waters first arise shall have the prior right to such water's if capable of being used upon his lands."

1 number of acts have been passed at different times providing for the sinking of artesian wells at certain localities and appropriating money therefor.

IDAHO.

The rights relating to subterranean waters in Idaho are thus defined (I.. 1899, p. 380, secs. 2 and 23 ) :

" The right to the use of the waters of rivers, streams, lakes, ponds, and subterranean waters may be acyuired by appropriation. 
"All ditchen now eonstructed. or" which may hereafter be constructed. for the purpose of utilizing seepage, waste, or spring water of the State shall be governed by the same laws relating to priority of right as those ditches, canals, and conduits constructed for the purpose of utilizing the waters of rumning streams."

MICHIGAN.

In the State of Michigan the (question of well interference is dealt with as follows:

"No person or persons, or corporation other than municipal corporations, owning or operating any artesian well, shall allow the same to flow a larger stream than will flow through a pipe 1 inch in diameter, to the detriment or injury of any other well or wells, without the consent of the owners of such well or wells so injured.

"Any pertion or persons who shall suffer any damage because of the violations of the provisions of this act shall be entitled to recover the same from the person or persons or corporations so causing the same, the action of trespass or the case to be brought in any court of competent jurisdiction.

"This act shall not apply to salt, oil, mineral water, or gas wells, or wells leased for bath purposes." (I.., 1889, p. 221.)

\section{NEBRASKA.}

In 1897 the following act was passed " to prohibit the needless waste of mutual artesian water in the State of Nebraska " (L., 1897, p. 358, chap. 84 , sees. $1-3)$ :

"That it shall be unlawful for the owner or owners, lessee or lessees, occupier or occupiers, foreman or superintentlent of any farm, town lot, or other real estate in the State of Nebraska where artesian water has been found, or may be found hereafter, to allow the water from wells or other borings or llrillings on any farm, town lot, or other real estate in Nebraska to flow out and run to waste in any manner to exceed what will flow or run throngh a pipe one-half of one inch in diameter, except where the water is first used for irrigation, or to create power for milling or other mechanical purposes.

"Any person or persons who own, occupy, or have control of any farm, town lot, or other real estate in the State of Nebraska who fail or refuse to shut off the wastage of artesian water to the amomit that this act allows on any farm, town lot, or other real estate which they own, occupy, or have control of, after being notified in writing by any person having the benefit of said mutual water supply, within forty-eight hours after such notification, shall be subject to arrest and, upon conviction, be fined in any sum not less than ten nor more than twenty-five dollars, and pay the costs of such arrest and prosecution 
for each offense: and if such wastage be not abaterl within twentyfour hours after such arrest and conviction, it shall be deemed a second offense against the provisions of this act and be subject to the same fine as for the first offense, and each like offense or neglect of cach twenty-four hours thereafter shall be deemed and constitute an arlditional offense against the provisions of this act.

" 111 prosecutions under the provisions of this act shall be brought ly any person in the name of the State of Nebraska against any person or persons violating any of the provisions of this act, before any justice of the peace of the county in which such violation is alleged to have taken place, or before any court of competent jurisdiction."

\section{NEVADA.}

In order to encourage the search for artesian waters in the State of Nevada, several acts and amendments thereto have been passed providing bounties for those who sink artesian wells. Thus it is provided that the party sinking an artesian well, where flowing water in a specified quantity is obtained, shall receive the following bomties: For the first 200 feet, $\$ 1.25$ per foot; for the third 100 feet, $\$ 1.50 \mathrm{per}$ foot; for the fourth 100 feet, \$2 per foot; and so on, up to $\$ 4.50$ per foot for the tenth 100 feet; and for all depth exceeding 1,000 feet $\$ 5$ per foot for each and every foot below the said 1,000 feet; together with an additional bounty of $\$ 1,000$ for each well sunk to a depth of 1,000 feet or more. Certain conditions relating to the number of wells allowable within a given area, the amount of water required, and the persistence of flow, are prescribed.

Uncler certain prescribed conditions a bounty of $\$ 2,500$ is offered to the person who first sinks a well in the State of Nevada, not lesis than $(i$ inches in diameter at the botton, to a depth of 1.000 feet, said well flowing at least 60 gallons of water per minute.

A person engaged in the sinking of an artesian well upon any unoccupied public lands snbject to selection by the State of Nevada, according to certain specified requirements, shall have a preferred right to all the lands he or she may be entitled to purchase under the provisions of certain acts providing for the selection and sale of the public lands of the State.

\section{NEW JERSEY.}

In 1904 an act (L., 1904, chap. 77, p. 188) was passed in New Jersey which empowered cities acquiring their water supply from artesian wells to improve and enlarge that supply, as follows:

"It shall and may be lawful for the governing board of any city now or hereafter acquiring its water supply from artesian wells, whenerer in their judgment they shall deem it expedient to do so, to cause to be constructed an additional pipe line or main to connect 
wroh water supply with any distributing reservoir within such city or with water-supply pipes or mains to any point within such city, and to dig and construct artesian wells, and to purchase and erect and to set up meters, machinery, and other fixtures in connection with and for the improvement of the water supply and waterworks plant of such city and to purchase and condemn land, waters, and rights, and otherwise to improve, enlarge, and extend said water supply and waterworks plant of such city, provided, howerer, that all such works shall be done and constructed by contract after public bidding therefor, in the manner prescribed in the laws now governing such city."

\section{NEW MEXICO.}

An act passed in 1897 authorizes any county in the Territory to issue and sell bonds for the purpose of sinking artesian wells. It states (L., 1897, chap. 66, sec. 2 ) that " the object of said wells shall be to ascertain whether flowing water can be procured on lands at present considered beyond and above the water belt - that is, above and beyond the belt wherein it has been demonstrated that flowing water can be obtained, and to encourage the boring of such well $r$ for the purpose of increasing the area and productiveness of our agricultural lands and to reclaim high mesa lands which are now ralueless for agricultural purposes."

By an act approved in 1903 the superintendent of the New Mexico penitentiary was anthorized to provide for the drilling of an experimental well on land belonging to the penitentiary.

\section{OKLAHOMA.}

The laws of Oklahoma have definitely embodied the general principles upon which the common-law decisions relating to the different rights in underground and surface waters are based. Thus it is stated (Revised and Annotated Statutes, 1903, chap. 65, Property, art. 3): "The owner of the land owns water standing thereon or flowing over or under its surface, but not forming a definite stream. Water ruming in a definite stream formed by nature over or under the surface may be used by him so long as it remains there, but he may not prevent the natural flow of the stream or of the natural spring from which it commences."

\section{OREGON.}

The rights to seepage and spring waters in the State of Oregon are thus stated (L., 1893, p. 150) : "All clitches now constructed, or herea fter to be constructed, for the purpose of utilizing the waste, spring. or seepage waters of the State shall be governed by the same laws relating to priority of right as those ditches constructed for the pur- 
pose of utilizing the waters of lumning streams: Provided, That the person upon whose lands the seepage or spring waters first arise shall have the right to the use of such waters."

\section{SOUTH DAKOTA.}

A great deal of legislation has been enacted in South Dakota conrerning artesian wells, especially acts providing for the sinking of such wells, defining the rights and liabilities of those who do sink them or who have control of them, and providing for the lerying of taxes and the issuing of bonds to pay the necessialy expenses. Those sections referring to official duties, the levying of taxes, etc., are not here considered, only the sections dealing more directly with subterrancan water's being citer.

By a series of acts (L., 1889, chap. 14; 1890, chap. 108; 1891, chap. 80; 1893 , chap. 109 ; 1895, chaps. 103, 106, 107, 108 ; 1897, chap. 74 ; 1903 , chaps. 63, (5t) and amendments thereto, it is provided that artesian wells may be sunk and watercourses be constructed therefrom upon petition of a majority of the qualified electors of any township in which the wells and the lands benefited thereby may be located; and that county, township, and special taxes may be levied to pay the cost of such wells and watercourses. ()r any person or persons, corporation or company may construct artesian wells upon lands leased by them, and construct watercoursen therefrom. the proprietor's of snch wells bearing the expense in proportion to their sereral interest. Certain restrictions are made regarding the number and location of waterways constructed from the wells, and the rights of parties controlling such waterways, of parties whose lands are crossed by them, and of the public are defined.

". Ill subterranean water's in the State of South Dakota may be used for irrigation, mechanical, and domestic purposes," according to the provisions stated in the several acts. One such provision requires the keeping of well records, as follows:

"It is hereby made the duty of the township board to emborly in the contract for the sinking of said public artesian wells a proviso that the person sinking said wells shall make a record of the depth of ach well and the formations entered or passed through in the construction of the same, and such provision is hereby made an essence of the contract and a violation thereof shall be construed to be a violation of the contract." (L.. 1891. chap. 80, sec. 35.)

The danger of "well interference " is recognized, and certain provisions made for avoiding the trouble, so far as is practicable. Thus it is provided (L., 1891, chap. 80, sec. 42) that ". Iny person, association, or corporation owning land shall have the right to sink or bore an artesian well or wells on his, their, or its lands, for the purpose of procuring water for domestic use, for irrigation, or for manufactur- 
ing purposes; but in wells hereafter constructed no more water shall be appropriated by such per'son, association, or corporation than is needed for said purposes, when such additional use of water interferes with the flow of wells on adjacent lands."

It has already been pointed out, in the first part of this report, that well interference may be foreseen and prevented to a greater or less extent by proper distribution of the wells. The decisions of the common law are in part based on the erroneous principle that it is impossible for any man to know until after his well is completed whether or not it will affect the flow of his neighbor's well. The State of South Dakota recognizes the possibility of foresceing and preventing well interference, and deals with the question in the following manner :

" In locating wells in townships which have established and put down wells under the provision of this act for public use or by pri. vate parties, due regard shall be had to their proper distribution. in order that the flow of the wells may be properly equalized and least likely to interfere with each other. Should any well in such township. public or private, be located so near any well already completed or in process of completion as to be likely to interfere with the same, any person may complain in writing to the State engineer, who shall without delay proceed to examine the locality and determine from its topography and the proximity of the wells whether. in his judgment, the wells as located would unduly interfere with the one already completed or in course of completion. If in his judgment there will be no material interference, the location will not be changed, but if in his opinion the well as located will materially interfere with the one completed or in course of completion he shall change the location of said well to some more suitable locality; provided, that when permanent buildings have been located on any farm prior to the sinking of any artesian well on any arjoining farm. this act shall not be construed as prohibiting the agent or proprietor of saicl farm from sinking an artesian well at or near said building without reference to the proximity of any other artesian well. The state engineer shall, within five days after said examination, make a written statement of his decision and file the same or a copy thereof in the office of the circuit court of the county wherein the said wells are located. Iny person aggrieved by the decision of the State engineer may, within ten days after the filing of the decision in the office of the clerk of the circuit court, appeal from the same to the circuit court and upon such appeal the question shall be tried de novo." (L., 1891, chap. 80, sec. 43.)

In order to determine whether the anount of water flowing from an artesian well is increasing or decreasing, the State engineer is 
required " to measure or to cause to be measured the flow and pressiure of all artesian wells established and put down under the provisions of this act, public and private, at such times as he may deem proper, for the purpose of determining the increase or diminution of the flow or pressure of said well, and is hereby authorized to enter upon any grounds for the purposes aforesaid, and the owner or owners of such well or wells are hereby directed to furnish the necessary material to construct a suitable reir to measure the flow, and all reasonable conveniences shall be aflorded for this purpose." (L., 1891, chap 80, sec. 44 .)

Every person sinking an artesian well is required to provide for such well a proper casing, in order to prevent the well from caving in and to prevent the escape of the water when it is desirable that such water be confined; and he is further recuired to provide such valve and appliances as will enable him to control the flow of the water from the well. Concerning the wating of artesian waters, it is provided (L.. 1891, chap. 80, sec. 46) that: " No person controlling an artesian well shall suffer or permit the water therefrom to flow to waste unless and so far as reasonably necestary to prevent obstruction thereof, or to How or to be taken therefrom sare for beneficial uses: Provided, Thim shall not be so construed as to prevent the reasonable use of said nater for the necessary irrigation of trees standing along or upon any -treet, road, or highway, or for ornamental ponds or fomtains, or the propagation of fish."

If any person complains that the proprietor of an artesian well, or the party controlling such well, is in the habit of letting the water's go to waste, the township supervisor, county commissioner, road overseer, alderman, or other city officers may enter upon the premises where the well is located in order to determine whether the complaint is justified. and may institute criminal prosecution in case violation of the law is arcertained. If the well is without valves to regulate the flow and prevent waste, the person owning the well may be fined up to one hundred dollars or be imprisoned not more than three months in jail, or both.

The flow of water through a watercourse from any artesian well is not to be interfered with, it being the duty of every person through whose land such a watercourse runs to keep the same open and nnobsructed. The road overseer must keep such watercourses along a public highway clear. It is further provided (L., 1893, chap. 109, sec. 3.2) that: ". All natural watercourses in this State, whenever an artesian well is located thereon under the provisions of this act, are hereby created and declared public natural watercourses for the flow of water from such artesian wells for the benefit of the public and of 
private individuals located on sincli watercourses, subject only to compensation for clamages as in this act provided."

UTAH.

"The waters of all streans and other sources in this State, whether flowing above or underground in known or definite channels, are hereby declared to be the proporty of the public, subject to all existing rights to the use thereof." (L.. 1903, chap. 100, sec. 47.)

\section{WASHINGTON.}

In the State of Washington the rights to seepage and spring waters are thus defined:

"All ditches now constructed or hereafter to be constructed for the purpose of utilizing the waste. seepage, or spring water's of the state shall be covered by the same laws as those ditches constructed for the purpose of utilizing the water of natural streams and lakes: Provided, 'That the person upon whose land the seepage or spring waters first rise shall have a prior right to such waters, if capable of being nsed upon his lands." (L., 1890, p. T10, sec. 15.)

In 1901 an act was passed " in relation to artesian wells and rexgl1lating the flow of waters therefrom: and providing a penalty for the violation thereof." (L., 1!01, p. 259, sec. 1-t.) The text of this act is given in full:

"It shall be unlaw finl for any person, firm, corporation, or company haring possestion or control of any artesian well within the State, whether as contractor. owner, lessee, agent, or manager, to allow or permit water to flow or escape from such well between the first day of ()etober in any year and the first day of April next ensuing: Promided. That this act shall only apply to sections and communities wherein the use of water for the purposes of irrigation is necessary or customary: And procided further, That nothing herein contained shall prevent or prohibit the use of water from such well between the first day of October and the first day of April next ensming for homsehold, stock, and domestic purposes onty, water for the last-named purposes to be taken from stich well through a one-half inch stop and waste cock to be inserted in the piping of such well for that purpose.

"It shall be the duty of every person, firm, corporation, or company having possession or control of any artesian well as provided in section 1 of this act to securely cap the same over, on or before the first day of October in each and every year, in such manner as to prevent the flow or excape of water therefrom, and to keep the same securely capped and prevent the flow or escape of water therefrom until the first day of April next ensuing: Procided, houreres. It shall and may be lawful for any such per'son, firm, corporation, or company to insert 
a one-haif inch stop and waste cock in the piping of such well and to take and use water therefrom through such stop and waste cock at any time, for household, stock. and domestic purposes, but not otherwise.

"Any person, whether the owner, lessee, agent or manager, having posisession of any such well, violating the provisions of this act shall be deemed guilty of a misdemeanor, and upon conviction thereof shall be fined in any sum not exceeding two hundred dollars for each and every such offense, and the further sum of two hundred dollars for each ten day's during which such violation shall continue.

"Whenever any person, firm, corporation, or company in possession or control of an artesian well shall fail to comply with the provisions of this aet. any person, firm, corporation, or company lawfully in possension of the land adjacent to or in the vicinity or neighborhood of such well, and within five miles thereof, may enter upon the land upon which such well is situated and take possession of unch, from which water is allowed to flow or escape in violation of the provisions of section 1 of this aet, and cap such well and shut in and secure the flow or escape of water therefrom. and the necessary expense incurred in so doing shall constitute a lien upon said well, and a sufficient quantity of land surrounding the same, for the use and operation thereof, which lien may be foreclosed in a civil action in any court of common jurisdiction. and the court in any such case whall allow the plaintifl a reasonable attorney's fee, to be taxed as a part of the cost. This shall be in addition to the penalty provided for in section 3 of this act."

\section{WISCONSIN.}

In the State of Wisconsin the questions of well interference and the wasting of artesian waters are thus dealt with:

" Where there are two or more artesian wells in any ricinity or neighborhood, one or more of which are operated or used by any person or owner, the person or owner of such well shall use due tare and diligence to prevent any losis or waste or unreasonable use of the water therein contained or flowing from the same, as would deprive or unnecessarily diminish the flow of water in any artesian well, to the injury of the owner of any other well in the same ricinity or neighborhood.

"Any person who shall needlessly allow or permit any artesian well owned or operated by him to discharge greater quantities of water than is reasonably necessary for the use of such person, so as to materially diminish the flow of artesian water in any other well in the

IRR $122-0.5 \mathrm{M}-4$ 
same vicinity, shall he liable for all damages which the owner of any such other well shall sustain." (L.. 1901, chap. 354.)

\section{WYOMING.}

According to the provisions of an act (L., 1888, chap. 19) passed in 1888, the boards of county commissioners of the several counties in the State of Wyoming are authorized to provide for the sinking of artesian wells at various places within such counties; and where the nature of the country makes an artesian well impracticable, tanks, reservoir's, etc., may be constructed. Certain restrictions are imposed, the rights and duties of private citizens and officials are defined, and appropriation of money is authorized. 


\section{N D E X.}

A.

Abloreviations, use of

Acme Oil co., Inillon $r$. See Dillon $r$. Acme Oil ('o.

Acton $r$. Blundell. decision in, on percolating waters _... 13-14

decision in, on well interfer-

enc'e _......... 17

Agrements, effect of

strict construction of $\ldots \ldots+31$

Alexander $r$. United States, decision in, on well interference

Alston v. Grant, decision in, on pollution

American and English Encyclopedia of law: Inderground Waters, citations from_

Angell, J. K., on nature of property in percolating water.-

Appropriation, prior, establishment of _.............

laws concerning Arid and humid States, different rules in _...- $20-21,32-33$

B.

Ball $v$. Nye, decision in, on pollution

Ballacorkish Mining Co. $r$. Harrison, decision in, on agreements

v. Dumball, decision in, on well interference

Ballard $v$. Tomlinson, decision in, on pollution _..........

Barrows, J., decision of, on motives_

Bartlett, J., decision of, on well interference ..........

Barnard $v$. Shirley, decision in, on disposal of intercepted water

decision in, on pollution

Bassett $r$. Salisbury Mfg. Co., decision in, on well interference _.........

decision in, on damming underground water

Baugh, Wheatley v. Nce Wheatley $r$. Baugh.

Bellows, r. .T., decision of, on motive

Bennett, E. H., on pollution
Page. | Benton, IIarwood $r$ see Ilarwood $r$ Benton.

Pilack, .I., decision of, on motives... Blundell, Acton $r$. N'C Acton $v$. Blundell.

Buston and Maine R. R., r'arker $r$. Sec Iarker r. Buston and Maine $k . k$.

Braintree Water Supply Co., proprietors of Mills $r$. see Proprietor's of Mills $v$. Braintree Water Supply Co.

Brett, M. R., decision of, on polIntion

Brinkerhoff, J., on public policy and rights in percolating water -...-

on motive

on prescription

Brookline, 'Trowbridge r., decision in, on well interference - 16-17 $^{-}$

Iirooklyn, Smith $v$. Sce Smith $v$. lirooklyn.

Brown, Strait $v$ : sce strait $r$. Brown.

Brown $r$. llitus, decision in, on pollution

Brown, Frazier $v$. See Frazier $v$. Brown.

\section{C.}

California, common-law decisions in $18,19,20-21,32-33,38,39$ statute law's of

Page.

Case $v$. Hoffman, decision in, on existence of underground streains

cemeteries, damage from Channels, underground, defined and known, definition of -Sif also Streams, underground.

Chasemore $v$. Richards, decision in, on stream-supply in. terference

Chartiers V. Gas Co., Collins $v$. Sec Collins $v$. Chartiers V. Gas Co.

Chauvet r. liill, decision in, on spring interference -.-

Chesley $\vartheta$. King, decision in. on motives

church, Womersley r. see Church $v$. Womersley. 
Clatk $r$. Lawrence, decision in, on pollution _.........

collins. l'ickard $C$ sece lickard $r$. Collins.

Coliins r. Chartiers V. Gas co., decision in, on precedents ...............

Colorado, statute laws of .... . . .

Coloring matter, underground transmission of, proofs by -.

connecticut, common-law cases in -cooley, .J., decision of, on pollution. corporations, status of, in resard to percolating water $16-1 \mathrm{~s} .: 2: 2$

('onin. Walker $r$. sec Walker $r$. (ronin.

'rops. injury to, hy alsstractious of percolating water _._- 1!1-:-1

cuts, swett $t$. sec swett $t$. Cutts

$$
\text { I). }
$$

bamming streams, right of ....... hammine noderglound water, damages from

Wickinson $x$, Trand Junction Canal ('o.. decision in, on stream-supply interference

Itillon $r$. Acme oil $r$, decision in,

bitches. Are sewer's. on pollution

Draining land, damages to water sul, liy from _.

lifour, Sovthern I'acific R. R. ('o. $r$ sec southern l'aeific R. R. C'o. r. Dufour.

Dumball, Ballacorkish Mining ('o. $x$. sec Ballacorkish Mining co. r. Inumball.

Durham, Porter $r$, on motives

$$
\text { I. }
$$

Ifster $x$. Apringfield, decision in, on spring interference ..

Excavating, damages to water sitpply from_... 16-1א, 27,32

\section{r.}

Fall River Iron Works ('o., Nherman $i$ sec sherman $r$. Fall River Iron Works ('o).

Farmer, stillwater Water co. $r$. Nec stillwater Water. ('o. $\iota$. Farmer.

Fletcher. Rylands $r$. Ác Itylands $r$. letcher.

Forbell $r$. New York, decision in, on injury to land .......

Howler. Jenkins $r$. Nec Jenkins $r$. Fowler. l'age.

Frazier $r$. Irown, derision in, on pulblic policy and rights in percolating water.-. decision in, on motives on prescription

G.

las refuse, pollution by

Gould, J. I., Law of Waters by, citations from

definition by

cilits

on artiticial percolation

on damming underground water's

on disposal of intercepted water's _...

Grand Junction Canal ('o., l)ickenson $r$. See lickinson i. Grand Junction ('anal Co.

Arand Junction Canal Co. $r$. Shugar, decision in, on artifirial percolation ......

Grant, Alston $v$. Sec Alston $v$. Grant.

Grants. Sce Agreements.

(iray. John C., acknowledgments to (ireencastle $v$. Irazelett, decision in, on pollution .........

Ground, imperfect support of, damage to water supply from -..........

(iumbert $r$. Kilgore, decision in, on spring interference -.32

10 $30-31$

II.

Hartison, Ballacorkish Mining Co. $r$. Ace Ballacorkish Mining ('o. $\iota$. IIarrison.

liant $r$. Jamaica Pond Aqueduct Co., decision in, on well interference _.........

Harwood $r$. Benton, decision in, on damming underground water

llathesly, Iord, L. I'.. decision of, on arlificial percolation

llazelett, fireentield $r$. Ncc (ireenfield $r$. Hazelett.

liill, chauvet $r$. s'c' Chauvet $r$. 11 ill.

lloffman, Case $r$. Nce ciase $r$. II offman.

lougan $v$. Milwaukee and Nt. I'aul R. R. "o.. decision in, on well interference --

I.

[daho, statule laws of _.......... 41-4:

Illins, Brown $r$ se Brown $r$. Illius.

Indiana, common-law cases in _.... 2.2, 28 
Injunctions, wranting of

Iowa, common-law decision in

$$
\text { .J. }
$$

Jacobs, Wheelock $v$. Ser Wheelock $r$. Jacolis.

Jamaica Pond Aqueduct ('o.. Hart r. Ser .Tamaica rond Aqueduct ('o. $r$. Hart.

Jenkins $r$. Fowler. decision in, un motive

Johnson, New River ('o. $r$. Nep New River ('o. $r$. Johnson.

Johnstown cheese Mfg. ('o. l. Veghte, decision in, on agreements

\section{K.}

Kata $r$. Walkinshaw, decision in, on well interference _... $20-21,32-33,98.39$

Kentueky, romnon-law cases in -..Kenyon, West cumberland Iron ( o. $r$. Nee West Cumberland Iron ('o, $r$. Kenyon.

kilgore, liumbert $r$ sce liumbert $\therefore$ Kilgore

King. chesley $r$ Ner chesley $t$. King.

Kinnaird r. Standard cil c'o., decision in. on pollution.

L.

Land, damages to, from interference with percolating water _._._._. 19-21, 33

land, drainage of, damages to water supply hy......

Law, common, on underground waters _._.

Law, statute, on underground waters _._.

Lawrence, Clark $r$. See ('lark $r$. Lawrence.

Lawyer's Reports Annotated, citations from ........

Lewis, (. .J., decision of, on indefinite character of percolating water

decision of, on motives on spring interference

\section{M.}

Martinsville, Skaggs $v$. Sec Skaggs $r$. Martinsville.

Massachnsetts, common-law decisions in $12,16,17,23,26,29$

Metropolitan Poard of Works, Regina $r$ Sce Regina $r$. Metropolitan Board of Wurks.

Michigan. statute laws of 16. 17
New York, common-law cases in $27,29,31$

New York, Forbell $\iota$. Nef Furbell $r$. New York.

Nowlen, Ihelps $r$ Sce Phelps $v$. Nowlen.

Nye, Liall $r$. Sec Ball $v$. Nye.

lercolating water, court precedents
concerning damming of, damage from _ _. 21,33 distinction between other real estate and _..._._._. 36-38

distinction between surface streams and _.__ 11-13, 82 existence of, presumption in favor of $f$

intorference with, damages from _........ $13-31$

knowledge of $\ldots, 24-38$ 
Percolating water, lack of agreement concerning _.....-. 34.38 legal rights in $12-31$ ownership in 13, 32. 36 pollution of _......... 25-28, 33, 36 priority of use of _.. $41-42,44-45,48$ public policy and rights in sale of, right of $-16,20-21,32-33,37$ waste of $1 \mathrm{~s}$

Jercolating waters, intercepted, disrosal of _._.

Percolation, artificial production of

lerry, Willis $t$. Sce Willis $v$ Perry.

Peterson, New Albany and salem R. R. Co. $x$. Nee New Albany and salem R. R. ('o. r. I'eterson.

Fhelps $r$. Nowlen, decision in, on motive _..........

Pickard $r$. Collins, decision in, on motive -

Pollution of underground water. liability for _...... $25-28$

Pollution. motive of

I'omeroy, .I. N., Water lights by. citations from ........

Porter r. Durham, decision in, on

motive _-.........--

Prescription, nonapplicability of _ 31-32, 34

privies. damage from _.___._. 26-27

I'roprietor's of Mills $r$. Braintree Water Supply ro., decision in, on artificial percolation _._-_...--

Inhlic policy, rights in percolating water and..........

R.

Reasonable use of percolating waters, decisions concerning - $15-16,20,22,28,32,33$

Regina $r$. Metropolitan Board of Works, decision in, on interference with springs _................

Reinbach, Wahle $v$, see Wahle $r$. Reinbach.

Reservoir, percolation from, damayes by ..........

Richards, Chasemore r. Sce Chasemore $r$. Richards.

Richland Tornship Co., Injohn $v$. Sfe Upjohn $r$. Richland Townslip Co.

Rocks, structural relations of, proofs of underground channels from

Rodman, J., decision in, on motive -

Rylands $v$. Fletcher, decision in, on artificial percolation -decision in, on pollution of underground water
S.

Page.

Salisbury Mfg. Co.. Bassett $v$. See Bassett $v$. Salisbury Mfg. Co.

Sewage, pollution by 25. 26

Sewers, construction of. damage to water supply by

Sherman $v$. Fall River lron Works Co., decision in, on pollution _........

Shirley, Barnard $v$. See Barnard $r$ Shirley.

Shugar, Grand .Iunction Canal Co. $v$. see Grand Junction Canal ('o. $x$. Shugar.-

Sink holes, proof of underground channel furnished by

Skaggs $v$. Martinsville, decision in on disposal of inter cepted waters

smith $r$. Brooklyn, decision in, on stream-supply interference

Solid matter, underground transmis sion of, proofs furnished by

Southern Pacific R. R. Co. v. Dufour, decision in, on spring interference ... 17-1?

Springfield. Elster $v$. See Elster $v$. Springfield _.............

Springs, grant of, implications of _.- 18, 31

interference with

streams from, riparian rights on

Standard Oil Co., Kinnaird $v$ See Kinnaird $v$. Standard Oil Co.

Stillwater Water Co. $v$. Farmer. de cision in, on spring interference _.......

strait $v$. Brown, decision in, on stream-supply interference

streams, surface, distinction between vercolating waters and _._._._. 11-13, 32

legal identity of underground streams and _..... 11,27,32 legal rights in and limitations on _.......... 11-12, 18

percolating water supply for, interference with _.. $18-19$, $2=-23,8: 3$

Streams, underground, distinction between percolating waters and _._._. 11-13, 32

legal identity of surface streams and _... 11,27

presumption àgainst existence of $9-10$ proofs of existence of _._____ 10-11

strong, 'F. R., decision of, on motive

Swett $v$. C'utts, decision in, on motive 
Temple, J., on nature of property in vercolating water

Tindal, C. J., on indefinite character of percolating water-- $13-14$

Tomlinson, Ballard $r$. Nee Ballard $v$ Tomlinson.

'Transmission, underground, proofs of channel furnished by

Trowbridge, $r$. Rrookline, decision in. on well interference _- 16-17

Turner $v$. Mirfield, decision in, on pollution

IT.

l'nderground water. See water, underground.

United states, Alexander v., derision in, on well interference

Upjohn $v$ Richland Township Co. decision in, on pollution

Utah, statute laws of

\section{$r$.}

Vault, percolating water from, damage by

Veghte, Johnstown Cheese Mfg. Co. v. sce Johnstown Cheese Mfg. Co. $v$. Veghte.

Vermont, common-law decisions in_- 18, 21

W.

Waddell, Wilson $v$ Sec Wilsen $v$. Waddell.

Wahle $v$. Reinbach, decision in, on pollution
Walker $v$. Cronin, decision in, on motive

Walker, George A., acknowledgments to

Walkinsliaw, Katz $v$ See Katz $v$. Walkinshaw _....... $\quad 16$

Washington, statute laws of

Water, underground, classes and definition of _._._... $9-10$

See also Streams, underground ; Percolating waters.

Wells, construction of, damages to other water supply from _ 14-17, 19, 22-23, 30-33 interterence with $14-17,32,45-46,49$ Wells, artesian, bounties for drilling of - 43

control of ..................... 40 definition of

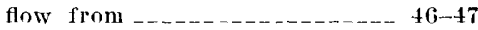
records of _..._. streams from, riparian rights on statite law's on $\ldots$ water from, waste of $\ldots 39-43,47-49$ disposal of _... pollution of _... 27-28

Wells, J., decision of, on motive _._. 29

West cumberland lron Co. $r$. Kenyon, decision in, on intercepted water _... 22

Wheatley $v$. Baugh, decision in, on spring interference _-- 18

on motive

Wheelock $v$. Jacobs, decision in, on spring interference _..- 18

Willis $r$. Perry, decision in, on well interference

Wilson $r$. Waddell, decision in, on artificial percolation $-2+$

Wisconsin, statute laws of _._._. $49-50$

Tomersley $r$. Cliurch, decision in, on pollution

Wyoming, statute laws of _... 50 


\section{PUBLICATIONS OF UNITED STATES GEOLOGICAL SURVEY.}

[Water-Supply Paper No. 122.]

The serial publications of the Uniter States (reological Survey consist of (1) Annual Reports, (2) Monographs, (3) Professional Papers, (4) Bulletins, (5) Mineral Resources, (6) Water-Supply and Irrigation Papers, (7) Topographic Atlas of United States-folios and separate sheets thereof, (8) Geologic Atlas of the United States-folios thereof. The classes numbered $2, \tau$, and 8 are sold at cost of publication; the others are distributed free. A circular giving complete lists may be had on application.

The Professional Papers, Bulletins, and Water-Supply Papers treat of a variety of subjects, and the total number issued is large. They have therefore been classified into the following series: A, Econonic geology; B, Descriptive geology; C, Systematic geology and paleontology; I, Petrography and mineralogy; E, Chemistry and plinsies; F, (iteography; (*, Miscellaneons; H, Forestry; I, Irrigation; J, Water storage; K, Pmmping water; L, Quality of water; M, l ieneral hydrographic investigations; N, Water power; ( I, Inlerground waters; P, Hydrographic progress reports. This paper is the thirty-fith in feries $\mathrm{O}$, the complete list of which follows. ( $P P=$ Profeswional Paper; $B=$ Bulletin; WS=IVater-Supply Paper. )

\section{SERIES O-ITNDERGROUND Waters.}

WS 4. A reconnaissance in southeastern Washington. by I. C. Russell. $1897,96 \mathrm{pp}, 7 \mathrm{pls}$.

WS 6. Underground waters of southwestern Kansas, by E. Haworth. 1897. 65 pp., 12 pls.

Ws 7 . Seepage waters of northern Utah, by Samuel Fortier. $1897.50 \mathrm{pp}, 3 \mathrm{pls}$.

Ws 12. I'nderground waters of southeastern Nebraska, by N. H. Darton. 1898. 56 pp., 21 pls.

W' 21. Wells of morthern Indiana, by Frank Leverett. 1899.82 pp., 2 pls.

WS 26 . Wells of southern Indiana (continuation of No. 21), by Frank Leverett. $1899.64 \mathrm{pp}$.

WS 30. Water resources of the Lower Peninsula of Michigan. by A. C. Lane. 1899.97 pp., 7 pls.

W' 31. Lower Michigan mineral waters, by A. 4 . Lane. 1899.97 pp., 4 pls

WS 34. Geology and water resources of a portion of southeastern South Dakota, by J. E. Todd. 1900. 34 pp., 19 pls.

WS 53. Geology and water resources of Nez Perces County, Idaho, Pt. I, by I. C Russell. 1901. 86 pl., 10 pls.

WS 54. Geology and water resources of Nez Perces County, Idaho, Pt. Il, by I. C. Russell. 1901. $87-141 \mathrm{pp}$.

WS 55. Geology and water resources of a portion of Yakima County, Wash., by G. O. Smith. 1901. 68 pp., 7 pls.

W'S 57. Preliminary list of deep borings in the Inited States, Pt. 1, by N. H. Tarton. 1902. 60 pp.

WS 59. Development and application of water in solthern California, Pt. I, by J. B. Lippincott. 1902. $95 \mathrm{pp}, \mathrm{p}, 11 \mathrm{pls}$.

WS 60. Levelopment and applieation of water in southern (alifornia, Pt. 11, by J. B. Lippineott. 1902. $96-140 \mathrm{pp}$.

WS 61. Preliminary list of deep borings in the United States, Pt. II, by N.H. Darton. 1902. (i7 pr.

Ws 67 . The motions ol underground waters, by C. S. Slichter. 1902 . $106 \mathrm{pp}, 8 \mathrm{pls.}$

B 199. Geology and water resourees of the Snake River Plains of Idaho, by I. C. Russell. 190\%, 192 pp., 25 pls.

Ws 77. Water resomrees of Molokai, Hawaiian Islands, by W. Lindgren. 1903. 62 pp., 4 pls.

WS 7x. Preliminary report on artesian basin in southwestern Idaho and southeastern Oregon, by I. (!. Russell. 1903. 5i3 pp., 2 pls.

PP 17. I'reliminary report on the geolgy and water resourees of Nebraska west of the one hundred and third meridian, by N. H. Darton. 1903. $69 \mathrm{pp} ., 43$ pls.

Wh 90, deology and wator resonres of part of the lower James River Valley, Sonth baketa, by J. E. Todd and C. M. Hall. 1904. 47 p.p., 23 pls. 
WS 101. Underground waters of southern Louisiana, by G. D. Harris, with discussions of their uses for water supplies and for rice irrigation, by II. L. Fuller. $1904.98 \mathrm{pp} ., 11 \mathrm{pls.}$

WS 102. Contributions to the hydrology of eastern United States, 1903, by H. L. Fuller. $1904.522 \mathrm{pp.}$

Ws 104. Underground waters of the Gila Valley, Arizona, by W. T. Lee. 1904.68 pp., 5 pls.

Ws 106. Water resoures of the Philadelybia district, by Florence Bascom. 1904. 75 pp., 4 pls.

Ws 110. Contributions to the hydrology of eastern United States, 1904; M. L. Fuller, geolcgist in charge. 1905. 211 pp., 5 pls.

PP 32. Geology and underground water recources of the eentral Great Plains, by N. H. Darton. 1905. $433 \mathrm{pp}, 72 \mathrm{pls}$

WS 111, Preliminary report on undergrumnd waters of Washington, by Henry Landes. 1905. 85 pp. $1 \mathrm{pl}$.

WS 112. Underflow tests in the drainage basin of Los Angeles River, by Homer Hamlin. 1905. 55 pp., 7 pls.

Ws 114. Underground waters of castem Inited states, by M. L. Fuller and others. 1905. 285 pp., 18 pls.

WS 11 h. Geology and water resources of eust-central Washington, by F. C. Calkins. 1905. 96 pp., 4 pls.

B 252. Preliminary report on the geolngy and water resources of central Oregom, by $\mathrm{r}$. C. Russell. 1905. $138 \mathrm{pp} ., 24 \mathrm{pls}$.

Ws 120. Bibliographic review and index of papers relating to underground waters published by the United States Geologieal Survey, 1879-1904, by M. L. Fuller. 1905. 128 pp.

Ws 122. Relation of the law to underground waters, by D. W. Johnson. $1905.55 \mathrm{pp}$.

The following papers also relate to this subjert: Tnderground waters of Arkansas Valles in eastern Colorado, by G. K. Gilbert, in Seventeenth Ammual, I’t. II; Preliminary report on artesian waters of a portion of the Dakotas, by N. H. varton, in Seventeenth Annual, Pt. Il; Water resources of Illinois, by Frank Leverett, in Seventeenth Annual. Pt. II: Water resources of Indiana and Ohio, by Frank Leverett, in Eighteenth Annual, Pt. $I:$ New developments in well boring and irrigation in eastern South Dakota, by N. H. Darton, in Eighteenth Annual, Pt. IV; Rock waters of Ohio, by Edward Orton, in Nineteenth Annual, Pt. IV; Artesian well prospects in the Atlantic Coastal Plain region, by N. H. Darton, Bulletin No. 138.

Correspondence should be addressed to

The Director,

United States Geological Survey,

APRIL, 1905.

Washington, D. C. 


\section{LIBRARY CATALOGUE SLIPS.}

[Mount each slip upon a separate card, placing the subject at the top of the second slip. The name of the series should not be repeated on the series card, but the additional numbers should be added, as received, to the first entry.]

\section{Johnson, Douglas Wilson.}

... Relation of the law to underground waters, by Douglas Wilson Johnson. Washington, Gov't print. off., I905.

55, iii p. $23^{\mathrm{em}}$. (U. S. Geological survey. Water-supply and irrigation paper no. 122)

Subject series: O, Underground waters, 35 .

1. Water-Laws and legislation. 2. Water, underground-U. S.

\section{Johnson, Douglas Wilson.}

... Relation of the law to underground waters, by Douglas Wilson Johnson. Washington, Gov't print. 迹 off., I905.

55, iii p. $23^{\mathrm{cm}}$. (U. S. Geological survey. Water-supply and irrigation paper no. 122)

Subject series: O, Underground waters, 35 .

1. Water-Laws and legislation. 2. Water, underground-U. S.

\section{U. S. Geological survey.}

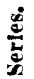

Water-supply and irrigation papers.

no. I22. Johnson, D. W. Relation of the law to underground waters. I905.

U. S. Dept. of the Interior. 